\title{
Contrasting reproductive biology of two hydrothermal gastropods from the Mid-Atlantic Ridge: implications for resilience of vent communities
}

\author{
Marticorena Julien ${ }^{1,{ }^{*}}$, Matabos Marjolaine ${ }^{1}$, Sarrazin Jozee ${ }^{1}$, Ramirez-Llodra E. ${ }^{2,3}$
}

${ }^{1}$ REM/EEP, Ifremer, 29280, Plouzané, France

2 Norwegian Institute for Water Research, Gaustadalleen 21, 0349, Oslo, Norway

${ }^{3}$ REV Ocean, Oksenøyveien 10, 1366, Lysaker, Norway

*Corresponding author : Julien Marticorena, email address : julienmarticorena@gmail.fr

\begin{abstract}
:
The recovery of populations and their ability to recolonise a disturbed habitat is mainly dependent on their reproductive biology (e.g., fecundity, frequency of reproduction, and time to maturity) and recruitment success. To assess recolonisation processes and connectivity of vent communities, and infer their resilience to natural and anthropogenic disturbances, we studied the life-history traits of two dominant species of vent gastropods from the northern Mid-Atlantic Ridge: Protolira valvatoides and Pseudorimula midatlantica. Gonad morphology, gametogenesis, and reproductive outputs related to shell length were described using histological analyses, and population structure was assessed from individuals' sizefrequency distributions. Samples were collected at different locations of the Montségur and Eiffel Tower edifices (Lucky Strike vent field) in April 2015, July 2017, and August 2018 to inform on spatial and temporal variations of their reproductive outputs and demography. All stages of oocyte development were found in the gonads of both species, suggesting a continuous gametogenesis and asynchronous reproduction. However, the two species showed contrasting reproductive strategies. Indeed, while P. midatlantica is gonochoric with a fecundity of up to 327 mature oocytes, $\mathrm{P}$. valvatoides is hermaphrodite with an extremely low fecundity including a maximum of eight vitellogenic oocytes. Maximum oocyte size was $176 \mu \mathrm{m}$ for $P$. midatlantica and $272 \mu \mathrm{m}$ for $P$. valvatoides. We infer from previous knowledge and our results that both species exhibit a lecithotrophic development of larvae. There was no evidence of temporal variability of reproductive traits, but environmental conditions seem to affect gametogenetic maturity and oocyte size of P. midatlantica limpets. Variations in population structure at the edifice scale suggest habitat selection of individuals related to biotic and abiotic factors.
\end{abstract}




\section{Introduction}

Current worldwide demand in minerals and metals is rising while land-based resources are severely decreasing (Hein et al. 2013). In this context, the interest of companies and countries in deep-sea mining is escalating, targeting various high metal-based environments such as Seafloor Massive Sulphide (SMS) deposits at hydrothermal vents, polymetallic nodules on abyssal plains and cobalt-rich ferromanganese crusts at seamounts (Gollner et al. 2017). Although commercial exploitation of seabed minerals has not yet begun, expected consequences of deep-sea mining on ecosystems comprise direct and indirect impacts that will vary with mining strategies (Ramirez-Llodra et al. 2011; Clark and Smith, 2013; Van Dover, 2014; Levin 2016) as well as with the biological and environmental characteristics of the targeted ecosystems (Gollner 2017). In this context, it is urgent to evaluate the resilience of deep-sea communities to inform the development of environmental management plans.

Resilience can be defined as the ability of an ecosystem to maintain its structure and function in response to a perturbation (Carpenter et al. 2001; Cumming et al. 2012). This definition involves two distinct processes: (1) resistance, related to the ability of a system to absorb the effects of disturbance without changing (Connell and Ghedini 2015) and (2) recovery, which is the capacity of an ecosystem to return to its undisturbed state (Ingrisch and Bahn 2018). Functional resilience occurs at multiple scales of ecological organisation, ranging from individual to community levels (Oliver et al. 2015). At the population-level, resilience refers to the ability of a species to occupy new space and recolonise a disturbed area. It is partly related to reproductive traits such as reproductive frequency, fecundity, time to maturity and recruitment success (see Gladstone-Gallagher et al. 2019). Thus, the recovery of impacted habitats is highly dependent on the dispersal and recolonisation potential of the different species.

Hydrothermal vents represent extremely fragmented and transient habitats that can be separated by tens to hundreds of kilometres along mid-ocean ridges and back-arc basins. Consequently, the recovery of impacted vent communities will strongly depend on larval 
supply reaching from preserved areas and on the success of recruitment events. Connectivity patterns are major drivers of the demographic stability of local populations. Two complementary methods can help to assess the connectivity between populations: i) population genetic based models (Tyler and Young 1999; Vrijenhoek 2010; Baco et al. 2016) and ii) coupled biophysical models that include ocean circulation and early life-history traits such as timing of spawning, fecundity, larval mortality and planktonic larval duration (Pradillon et al. 2001; Metaxas and Saunders 2009; Hilario et al. 2015; Suzuki et al. 2018; Vic et al. 2018). However, despite their relevance, discrepancies in the results of these modelling approaches highlight a lack of knowledge of both physical and biological variables in deep-sea ecosystems (Breusing et al. 2016). Indeed, for most deep-sea species, empirical data on early life-history traits is, at best, fragmentary but often completely lacking (Tyler and Young 1999). It is therefore urgent to increase our knowledge about the natural processes driving population connectivity, colonisation patterns and ecosystem recovery, to better understand the resilience of vent communities following a disturbance (Mullineaux et al. 2010; Gollner et al. 2015; Boschen et al. 2016; Gollner et al. 2017).

Hydrothermal vent communities in the northern part of the mid-Atlantic ridge and specifically at the Lucky Strike vent field (LS) are characterised by dense assemblages of macrofauna, structured by the engineer species Bathymodiolus azoricus. B. azoricus mussel beds provide a three-dimensional habitat promoting high-density populations of gastropods (Protolira valvatoides, Pseudorimula midatlantica, Lepetodrilus atlanticus) and polychaetes (Branchipolynoe seepensis, Amphisamytha lutzi (Cuvelier et al. 2014; Sarrazin et al. 2015). While basic reproductive traits are known for most species in the area, only the reproductive biology of B. azoricus, L. atlanticus, B. seepensis and A. lutzi has been described in details (Van Dover et al. 1999; Jollivet et al. 2000; Blake and Van Dover 2005; Colaco et al. 2006; Dixon et al. 2006; Tyler et al. 2008), and our knowledge of gastropods remains limited. Gathering this information is key in understanding the establishment of vent faunal communities and ecosystem functioning. 
101 storage of energetic reserves in the growing oocytes, appears to be phylogenetically constrained (Eckelbarger 1995; Tyler and Young 1999). In contrast, the number and quality of the eggs, and also the time of spawning, can be affected by environmental conditions 104 (Ramirez-Llodra 2002; Kelly and Metaxas 2007; Matabos and Thiebaut 2010). The continuous supply of energy introduced in the food web by chemoautotrophic bacteria at hydrothermal vents can support an asynchronous and quasi-continuous production of eggs by benthic species, but seasonal reproduction has also been observed in bathymodiolin mussels (reviewed by Laming et al. 2018). Energy availability can also shape the trade-off between egg size and fecundity (Ramirez-Llodra 2002), and the size of mature oocytes can provide information about larval development mode and help determining the type of larvae. Planktotrophic larvae are those feeding in the water-column, while lecithotrophic larvae feed on the egg's yolk until settlement. As a general pattern, species producing a large number of small eggs $(<200 \mu \mathrm{m})$ have planktotrophic larval feeding modes, while lecithotrophic species produce a small number of larger eggs (> $200 \mu \mathrm{m}$ ) (Jaekle 1995; Levin and Bridges 1995). For molluscs, larval shell morphology has also been used to infer larval development and dispersal, based on observations of shallow-water species (Gustafson and Lutz 1994). Protolira species are hermaphroditic and have a spirally coiled propodial appendage interpreted as a penis and thus with assumed pseudo-internal fertilization occurring in the pallial cavity (Warén and Bouchet 1993. P. midatlantica (Mclean 1992) is described as gonochoristic and characterized by a hypertrophied gonad that displaces the foot on the left side of the animal, probably in response to the need of a greater reproductive output (Mclean 1992).

123 In this study, we describe for the first time the gametogenesis, population structure and infer 124 the reproductive output at the time of sampling of two abundant MAR gastropods (Protolira 125 valvatoides and Pseudorimula midatlantica), providing novel data to better assess the recovery potential of vent ecosystems in face of natural and anthropogenic disturbances. This

127 work is part of a larger study that aims at evaluating the rate and success of recovery of active 128 hydrothermal vent communities after an induced disturbance using a 2 year in situ experiment. Community recolonisation one year and two years after disturbance (faunal removal) was monitored and the role of biological and chemical factors on recolonisation dynamics evaluated. 


\section{Material and Methods}

\section{Field sampling}

134 All specimens of Protolira valvatoides and Pseudorimula midatlantica were sampled using the hydraulic arm and suction sampling device of the Remotely Operated Vehicle Victor6000. They were collected in Bathymodiolus azoricus assemblages on diffused flow habitats on the

137 Montségur and Eiffel Tower edifices (Lucky Strike vent field, MAR) at $1700 \mathrm{~m}$ depth (Fig. 1).

138 To investigate spatial variation of reproductive and population structure features, samples

139 were collected at different sampling locations with varying environmental conditions (Fig. 1,

140 Table 1). Sample names refer to a disturbance experiment that was held on the Montségur

141 edifice from 2017 to 2019. Individuals from three cruises, occurring in May 2015

142 (MOMARSAT2015), July 2017 (MOMARSAT2017) and August 2018 (MOMARSAT2018), were compared to test for temporal variations across the two species.

To complete the dataset, in situ temperature measurements were conducted year-round with autonomous MISO (2015, WHOI-MISO low temp-ONSET ${ }^{\circledR}$ ) and iButtons $^{\mathrm{TM}}$ (2017 and 2018) probes deployed directly on the mussel assemblages.

On board, all faunal samples were washed on a $300 \mu \mathrm{m}$ sieve and gastropods were identified to species level. Five to twenty individuals of $P$. valvatoides and $P$. midatlantica from each sample were stored in buffered $4 \%$ formaldehyde for reproduction studies, whereas all other specimens were preserved in $96 \%$ ethanol for population structure analyses.

\section{Population structure}

155 Size-frequency distributions of both species were only analysed for the samples from the 156 Montségur edifice, as most of the Eiffel Tower specimens were used for other analyses and 157 therefore not measured. To characterize demographic population structure, photos of $P$. 158 midatlantica and $P$. valvatoides were captured with a Leica MC 170 HD camera mounted on a 159 Leica M125 dissecting microscope. The curvilinear distance (i.e. longest length from the apex to the anterior edge of the shell along the dorsal side) of $P$. midatlantica and the longest shell

161 dimension of $P$. valvatoides (see Bates et al. 2006 for protocol) were measured to the nearest $0.001 \mathrm{~mm}$ using the Leica Application Suite software. Measurement error was calculated as 
163 the maximum difference among 10 measures of the same individual on 10 specimens 164 comprising a range of all sizes for each species. It was fixed at $0.052 \mathrm{~mm}$ for $P$. midatlantica 165 and $0.029 \mathrm{~mm}$ for $P$. valvatoides.

166 For each assemblage sampled, length-frequency distribution was plotted for the two species 167 using a size-class interval of $0.3 \mathrm{~mm}$ for $P$. midatlantica and $0.2 \mathrm{~mm}$ for $P$. valvatoides. The intervals were chosen according to three criteria: i) most size-classes must have at least five 169 individuals; ii) the number of adjacent empty classes must be minimized; and iii) the interval 170 has to be much greater than the measurement error (see Jollivet et al. 2000). Size-frequency 171 distributions were compared to a normal distribution using a one-sample Kolmogorov172 Smirnov test and non-parametric Kruskal-Wallis multisample tests were performed to identify 173 differences in size-frequency distribution between samples. To determine which individuals 174 contributed to the observed differences, multiple comparison Nemenyi and Dunn tests were 175 computed (Zar, 2007).

177 When distributions differed significantly from a normal distribution, and assuming that 178 gastropod sizes followed a Gaussian distribution within each cohort, a modal decomposition 179 was ran for all sampled assemblages of $P$. valvatoides. Modal decomposition analyses were 180 not performed for $P$. midatlantica because at least 100 to 300 specimens are required to have 181 a fairly good representation of the population, which was not the case in some of our samples 182 for this species. The modal decomposition analyses of $P$. valvatoides was conducted with the 183 Mixdist package (Macdonald and Du, 2018) in R (RStudio Team, 2016), which identifies the 184 total number of cohorts within the natural distribution and calculates the mean size, standard 185 deviation and proportion of the overall population in each cohort. The goodness of fit of 186 identified size cohorts was verified using a chi-squared test. Seven individuals of $P$. valvatoides 187 were removed from the distribution of $\mathrm{C} 1 \mathrm{a}, \mathrm{C} 1 \mathrm{acg}$ and R1 before the MIX analysis to avoid 188 null classes separating the modes. 
192 The shells of $P$. midatlantica were gently removed using forceps, while $P$. valvatoides 193 individuals were rapidly decalcified using a $\mathrm{HCL} 10 \%$ solution before removing the 194 periostracum under a dissecting microscope. The entire soft body was then processed through 195 graded ethanol and dehydrated in absolute isopropanol before being embedded in paraffin 196 wax. For histological analyses, serial horizontal $7 \mu \mathrm{m}$ thick sections of gonads were prepared 197 using a microtome. Sections were stained with the routine staining haematoxylin and eosin 198 protocol (Gabe, 1968). Observations were performed using the AxioZoom stereomicroscope 199 (Zeiss, Oberkochen, Germany) equipped with an ApoTome.2 slider module (Zeiss) and a HXP $200200 C$ light technology (Zeiss) and using an AxioCam MRm (Zeiss) camera. Micrographs were 201 analyzed using the Zen (Zeiss) software.

202

203 204 205 206

For gametogenesis studies, at least 100 oocytes per specimen were measured using the image J (C) software (Schneider et al. 2012) from 2 to 3 serial sections for $P$. midatlantica. For $P$. valvatoides, the very low number of oocytes was insufficient to reach 100 oocytes even when using serial sections of the entire gonad. Only oocytes that had been sectioned through the nucleus were measured using the feret diameter, which estimates the diameter of a hypothetical disc with the same area as the measured object. Oocyte sizes were grouped into $10 \mu \mathrm{m}$ classes for frequency diagrams constructed for each sampling location. To assess synchrony of gametogenesis among and between samples, non-parametric Kruskal-Wallis multi-sample and Nemenyi and Dunn tests were performed on oocyte size. Gametogenetic maturity was estimated from the percentage of vitellogenic oocytes on the total of oocytes measured for each animal and comparisons among samples were made using the same methods as previously described.

Instantaneous fecundity was quantified as the number of vitellogenic oocytes in the entire ovary of an individual at the time of sampling (Tyler and Billett 1988; Ramirez-Llodra 2002). Fecundity was quantified in 10 individuals for $P$. midatlantica and 9 individuals for $P$. valvatoides. To ensure that a vitellogenic oocyte was not counted more than once, the overlying sections were compared. 


\section{Results}

\section{Environmental conditions}

The mean temperatures measured over the year within the different quadrats varied between 5.1 and $8.3^{\circ} \mathrm{C}$ and were typical of a diffuse flow venting area (Table 1). Significant spatial variations of mean temperature have been identified with the presence of warmer habitats in R1, C2a and C1a quadrats (ANOVA, $F=6591$, p-value $<0.001$ ).

\section{Gonad morphology and gametogenesis}

In total, 58 individuals of Protolira valvatoides and 34 females of Pseudorimula midatlantica, collected at different sampling locations, over three years, were analyzed (Table 1).

The hermaphroditic genital system of Protolira valvatoides consists of separate ovary with oviduct and a testis with a vas deferens (Fig. 2a and c). The large ovary is situated dorsally and occupies, together with the digestive gland, the uppermost whorl of the shell (Fig. 2a and c). The testis is located anterio-ventrally of the ovary, extending on the right side of the animal. Spermatogenesis begins with the development of germinal spermatogonia with a mean diameter of $4 \mu \mathrm{m}$ from the wall of testis tubules. Spermatogonia differentiate in spermatocytes and spermatids via mitotic divisions, before developing into flagellated spermatozoa in the lumen of the testis (Fig. $2 \mathrm{~g}$ ). During oogenesis, the oogonia proliferate in the germinal epithelium, which extends throughout the entire ovary. Oogonia grow to approximatively $20 \mu \mathrm{m}$ before developing in previtellogenic oocytes. Oogonia appear in histological sections as small cells with a large and dark stained nucleus occupying the entire cell, while previtellogenic oocytes are larger $(20-100 \mu \mathrm{m})$ with a basophilic and more voluminous cytoplasm that stain in light purple (Fig. 2e). Previtellogenic oocytes grow until reaching $80-100 \mu \mathrm{m}$, when they undergo vitellogenesis. At the beginning of vitellogenesis, yolk granules are visible at the periphery of the oocytes and spread to the entire oocyte.

249 Vitellogenic oocytes show an eccentric germinal vesicle and acidophilic cytoplasm stained in pale pink with eosin (Fig. 2e). For Protolira valvatoides, the mean size of vitellogenic oocytes was $185 \mu \mathrm{m}$ (ferret diameter) and the maximum size measured was $272 \mu \mathrm{m}$. 
253 Pseudorimula midatlantica is a gonochoric species with separated male and female 254 individuals. In females, the ovary occupies a large volume of the animal, extending from the 255 very posterior end to the pallial roof on the right side (Fig. 2b). It is ventrally replaced by the 256 stomach and digestive glands and surrounded on both sides by the shell muscle (Fig. $2 \mathrm{~d}$ ). The 257 development and maturation of oocytes and spermatozoa are similar to $P$. valvatoides (Fig. $2582 \mathrm{H}$ ). In the ovary, the previtellogenic oocytes grow to a size of $40-50 \mu \mathrm{m}$ before starting 259 vitellogenesis (Fig. 2f). The mean size of vitellogenic oocyte for P. midatlantica was $81 \mu$, 260 with a maximum size of $176 \mu \mathrm{m}$, and yolk was distributed all over the oocyte (Fig. 2f). All 261 developmental stages of oocytes (i.e. oogonia, previtellogenic oocytes and vitellogenic oocytes) were observed in all individuals analysed for both species.

Oocyte size-frequency distribution

265 For both species, oogonia were much more abundant in ovaries than previtellogenic and vitellogenic oocytes. Hence, oogonia were not considered for oocyte-size distribution analyses. For both species, the Kruskal-Wallis multisample test showed intra-sample differences in mean oocytes size and the post-hoc Dunn's multi-sample test indicated that only one to three individuals of each sample contributed to these differences (Table S1). To ensure that there was no individual size effect among samples in testing the spatial and temporal variation of oocyte distribution, we compared shell length of the examined individuals. No significant differences were identified (Test Kruskal-Wallis, $\mathrm{H}=0.44, \mathrm{df}=7, \mathrm{p}$ value $>0.05$ for $P$. valvatoides and $\mathrm{H}=11.07, \mathrm{df}=7, \mathrm{p}$-value $>0.05$ for $P$. midatlantica). Oocyte size-frequency distributions were highly variable between individuals and there was no evidence of synchronous oogenesis. However, the two species displayed the same polymodal pattern in oocyte-frequency distribution skewed towards smaller oocytes with a tail in larger sizes that may contain several modes (Figs. 3 and 4).

For $P$. valvatoides, oocyte size ranged from 9 to $272 \mu \mathrm{m}$ (Fig. 3) and the size-frequency distribution showed a first peak containing between 91 and $96 \%$ of the total number of oocytes, corresponding to previtellogenic oocytes $(<100 \mu \mathrm{m})$. The rest of the distribution contained one or more peaks of larger oocytes $(>100 \mu \mathrm{m})$, corresponding to previtellogenic oocytes at the onset of vitellogenesis and truly vitellogenic oocytes. Kruskal-Wallis multisample tests showed that oocytes size distributions between locations and sampling period 
did not differ significantly (Fig. 5a and c, Fig. S1). The percentage of mature oocytes ranged from $3 \%$ to $18 \%$ of all oocytes and was not correlated with the animal body length $\left(R^{2}=-0.014\right.$, $\mathrm{p}$-value $=0.91)($ Fig. 6a). Finally, no difference was observed regarding the proportion of vitellogenic oocytes among localities (Kruskal-Wallis test, $\mathrm{H}=7.23, \mathrm{df}=5, \mathrm{p}$-value $>0.05$; Fig. 5c)

For P. midatlantica, oocyte size ranged from 4 to $176 \mu \mathrm{m}$ (Fig. 4) and size frequency distribution showed a first peak, containing between 31 and $82 \%$ of the total population, which corresponded to previtellogenic oocytes $(<50 \mu \mathrm{m})$. A second and minor peak was mostly constituted by larger vitellogenic oocytes $(>50 \mu \mathrm{m})$. An intermediate peak including oocytes at the beginning of vitellogenesis (between 40 and $50 \mu \mathrm{m}$ ) was also present for most of the localities (Fig. 4). P. midatlantica showed a significant spatial variation in oocyte size distribution among the different sites with smaller oocytes in the C1a sample and larger oocytes in the C2a sample (Fig. 5b and d). Nevertheless, there was no evidence of temporal variation in mean oocyte size of $P$. midatlantica (Fig. S2). For this species, the percentage of mature oocytes was independent of body size and ranged from $6 \%$ to $51 \%$ of all oocytes (Fig. $6 \mathrm{~B})$. The percentage of mature oocytes varied significantly among localities, with a larger proportion of vitellogenic oocytes in the C2a and R1 samples (Kruskal-Wallis test, $H=19.43$, $d f=6, p$-value $<0.005)$.

Fecundity

An estimation of instantaneous fecundity was measured from individuals randomly selected among the C1a sample. In total, 9 individuals of $P$. valvatoides with sizes ranging from 2.2 to $3.4 \mathrm{~mm}$, and 10 females of $P$. midatlantica, with shell lengths comprised between 4.1 and 8 $\mathrm{mm}$, were analysed. In this study, even the smallest individuals examined possessed vitellogenic oocytes, so it was not possible to assess the minimal size at first maturity. Furthermore, for both species, mature individuals with shell length about half of their maximum size have been found. In $P$. valvatoides, the maximum instantaneous fecundity was very low, with only 8 vitellogenic oocytes through the entire ovary. Fecundity appears to be independent of animal size for the 9 individuals analysed $\left(R^{2}=0.007, p\right.$-value $\left.=0.34\right)$. Mean instantaneous fecundity of $P$. midatlantica was $187 \pm 44$ oocytes per female, with a maximum of 327 oocytes found in an individual with a length of $8 \mathrm{~mm}$. Fecundity and shell length showed 
317

a positive linear relationship for the 10 examined specimens of $P$. midatlantica $\left(R^{2}=0.84, p\right.$ value $<0.001)$.

\section{Population structure}

The demographic structures of the two species for each sample collected on Montségur in 2017 are presented in Figures 7a and b. All frequency distributions significantly differed from the normal distribution (Kolmogorov-Smirnov test, $p$-value $<0.001$ ) and were thus assumed to be polymodal. For $P$. valvatoides, specimens ranged in shell length from 0.51 to $3.84 \mathrm{~mm}$. Distributions were dominated by large individuals with a major peak between 2 and $2.5 \mathrm{~mm}$ (Fig. 7). However, while the chi $^{2}$ tests associated with the MIX modal decomposition highlighted no significant differences between the observed and obtained theoretical distributions, the low level of acceptance did not allow to determine reliable cohorts within the studied population. This might be due to the limited number of individuals analysed, or related to processes other than discontinuous recruitment. The Kruskal-Wallis multi-sample test identified significant differences in size-frequency distribution between the different samples $(H=49.424, d f=3, p$-value $<0.001)$ and the post-hoc Dunn's multi-sample test showed that every sample was different from each other, except for C1acg which is not significantly different from C2a and R1 (Table 2).

The low abundance of $P$. midatlantica did not allow to perform modal decomposition analysis, but the size distribution is highly variable across the different samples with, for example, a mean size of $2.4 \pm 0.7 \mathrm{~mm}$ in the C1a sample against $3.7 \pm 1.1 \mathrm{~mm}$ in C2a. The Kruskal-Wallis multi-sample test confirmed the observed difference among the localities $(H=112.04, d f=6$, p-value $<0.001)$ and the post-hoc multiple Dunn's test highlighted significant differences between most of the samples, except for the C1b which contained only 16 individuals (Table 2).

\section{Discussion}

\section{Reproductive anatomy}

The reproductive anatomy of Protolira valvatoides and Pseudorimula midatlantica showed some differences leading to distinct reproductive attributes. Protolira valvatoides is a 
simultaneous hermaphroditic gastropod with separated ovary and testis, characterized by the presence of a propodial penis (Warén and Bouchet 1993) and internal fertilization as most of the Skeneidae species (Haszprunar et al. 2016). Internal or pseudo-internal (i.e. entaquatic)

351 fertilization is an advantageous strategy adopted by many vent species that could ensure a 352 high level of fertilization by preventing the rapid dilution of gametes in the turbulent flow 353 regime of vents (Fretter 1989, Tyler and Young 1994, Hilario et al. 2005). Conversely, 354 Pseudorimula midatlantica is a gonochoric species with a large ovary occupying almost a third 355 of the body size. Unlike other genera of the Lepetodrilidae family (e.g. Clypeosectus, 356 Gorgoleptis and Lepetodrilus), Pseudorimula lack secondary reproductive organs such as a 357 penis or seminal groove (Haszprunar 1989; Warèn and Bouchet 2001) and no vesicle containing sperm or fertilized oocytes have been found in females of this study. However, Haszprunar (1989) identified the presence of ripe spermatozoa in contact with mucous droplets of the prostate gland in Pseudorimula marianae males, suggesting an entaquatic fertilization occurring after copulation in the female mantle cavities when oocytes are released in the sea water. While the two species analysed in this study are known to be associated with Bathymodiolus azoricus in cold habitats (Sarrazin et al. 2015), warmer fluid zones can be as close as few to tens of centimetres (Sarrazin et al. 2014; Matabos et al. 2015). Gametes released in seawater could thus easily be exposed to temperature above $100^{\circ} \mathrm{C}$. Some deep-sea gastropods are known to enclose embryos within egg capsules or gelatinous mucus to protect them from harsh conditions (Berg 1985; Gustafson et al. 1991; Bouchet and Warén 1991; Warén and Bouchet 2001; Martell et al. 2002; Watanabe et al. 2009), but to our knowledge, none of the species belonging to the two investigated families display this type of development.

\section{Gametogenesis}

373 The two species investigated displayed a similar gametogenic pattern with the presence of all 374 stages of oocyte development. The small oogonia of around $20 \mu \mathrm{m}$ develop from the germinal epithelium and evolve to previtellogenic oocytes. These previtellogenic oocytes reach 80-100 $\mu \mathrm{m}$ for $P$. valvatoides and $40-50 \mu \mathrm{m}$ for $P$. midatlantica, after which they undergo 377 vitellogenesis, with a mean size of $185 \mu \mathrm{m}$ for $P$. valvatoides and $81 \mu \mathrm{m}$ for $P$. midatlantica. 378 The polymodal distribution and the absence of temporal variation of oocyte-size frequency 379 identified in this study for both species suggest iteroparity with a quasi-continuous and 
asynchronous gametogenesis among individuals. These reproductive patterns have been observed in many vent gastropod families such as Lepetodrilidae (Kelly and Metaxas 2007; Tyler et al. 2008, Bayer et al. 2011; Nakamura et al. 2014), Peltospiridae (Fretter 1988; Matabos and Thiebaut 2010) and Sutilizonidae (Hazsprunar 1989; Gustafson and Lutz, 1994). Continuous or quasi-continuous gametogenesis is also found in other vent taxa, including polychaetes (e.g. Alvinellidae, Ampharetidae, Polynoidae, and Siboglinidae families; McHugh and Tunnicliffe 1994; McHugh 1995; Zal et al. 1995; Van Dover et al. 1999; Jollivet et al. 2000; Blake and Van Dover 2005), shrimps (e.g. Rimicaris chacei, Mirocaris fortunata; RamirezLlodra et al. 2000) and amphipods (Halice hesmonectes, Bouvierella curtirama; Sheader et al. $2000 ; 2004)$. This continuity in gametogenesis may be linked to the continuous supply of energy in the vent environment, introduced in the food web by chemoautotrophic microorganisms (Tyler et al. 1994). Thus, invertebrate species can allocate a constant supply of energy for egg production and enhance the number of offspring throughout the year. However, despite the absence of energy limitation, some vent species such as Bathymodiolus azoricus display a seasonal reproduction with an annual emission of gametes around January (Colaço et al. 2006; Dixon et al. 2006). Their periodic spawning and fertilisation events and development of embryos into planktotrophic larvae seem to be linked to the seasonal input of phytoplankton detritus from the surface sinking through the water column to the seafloor (Gage and Tyler, 1991; Eckelbarger and Watling, 1995).

\section{Reproductive output}

The maximum oocyte-size found in $P$. midatlantica $(176 \mu \mathrm{m})$ fell in the range of sizes previously observed in the Lepetodrilidae family. Oocytes are larger than those of Lepetodrilus atlanticus, L. elevatus and L. ovalis, but in the same order of magnitude as those of $L$. fucensis, L. cristatus, L. pustulosus and L. tevnianus (Fretter 1988, Kelly and Metaxas 2007; Tyler et al. 2008; Matabos and Thiebaut 2010; Bayer et al. 2011). Oocyte size is commonly used as an indicator of larval development mode. This assumes that large oocytes accumulate more yolk and can provide enough energetic resources for a lecithotrophic nutrition when the larvae disperse in the water column feeding only on the reserves accumulated in the eggs. On the contrary, smaller eggs do not contain enough food reserves to support dispersing larvae, and thus these larvae are mostly planktotrophic, feeding on bacteria, phytoplankton or detritus in the water-column (Tyler 1988). The maximum egg size of $176 \mu \mathrm{m}$ for Pseudorimula 
412 midatlantica suggests a planktotrophic development for this species (Jaekle 1995; Levin and 413 Bridges 1995). However, for lepetodrilid species egg size appears to be a poor indicator of 414 larval development (Tyler et al. 2008). For instance, even if all lepetodrilid species studied to 415 date display quite small maximum oocytes size $(<200 \mu \mathrm{m}$, Table 3$)$, the morphology of their 416 larval shell is consistent with a lecitothrophic development (Tyler et al. 2008, Lutz et al. 1986). 417 This trait was proposed to reflect a phylogenetic constraint on vent taxa (Lutz et al. 1984). In 418 general, larvae that are dependent on the energy from the yolk have a limited dispersion 419 ability compared to planktotrophic larvae (Levin 2006). However, it has been demonstrated 420 that for deep-sea species, cold temperatures can lead to a reduction of the metabolism and a 421 delay of metamorphosis. This would enhance planktonic larval duration (PLD), suggesting the 422 potential for a wider dispersal range (Pradillon et al. 2001; Young 2003, Watanabe et al. 2006; 423 Adams et al. 2012).

424

425 When analysing the spatial variation of mean oocyte size and individual maturity for $P$. 426 midatlantica within LS vent field, we observed differences at the edifice scale, with larger 427 oocytes and higher proportion of mature oocytes in individuals of the C2a and R1 sites and 428 lower values in the C1a sample. In C1a, there was only one female among the 10 examined 429 individuals that could account for the observed difference in mean oocyte size compared to 430 other samples. Interestingly, the C2a and R1 locations displayed the warmer and more 431 variable temperatures, with mean temperature of $6.6 \pm 0.9{ }^{\circ} \mathrm{C}$ for $\mathrm{C} 2 \mathrm{a}$ and $8.3 \pm 1.1^{\circ} \mathrm{C}$ for 432 R1 compared to $5.7 \pm 0.26$ in C1a. The same observation was reported by Kelly and Metaxas 433 (2007) between active and senescent habitats for L. fucensis in the Juan de Fuca Ridge. These 434 authors showed poorly developed oocytes and lower fecundity in species inhabiting senescent 435 environments, suggesting an influence of habitat characteristics on reproductive outputs (i.e. 436 fecundity and oocyte size). Indeed, the proximity of vent emissions of warmer habitats might 437 enhance chemoautotrophic production (Guezennec et al. 1998, Sievert et al., 2000) and 438 provide a greater food supply for gastropods, allowing individuals to allocate more energy in 439 vitellogenesis.

441 Female fecundity and shell size showed a strong linear relationship in P. midatlantica. The 442 size-dependence of fecundity is a characteristic among many invertebrates, since larger 443 females are able to enhance their resource acquisition and allocate them to reproductive 
444 processes (Bridges et al. 1994; Ramirez-Llodra 2002). This can also be supported by a positive 445 correlation between body size and the volume of the ovary that may contain more oocytes 446 (Honkoop and Van der Meer 1997). The maximum instantaneous fecundity of $P$. midatlantica 447 was 327 oocytes, measured in an individual of $8 \mathrm{~mm}$. The lower fecundity of $P$. midatlantica 448 compared to other species of Lepetodrilid (Table 3) can be a result of the difference observed 449 in oocyte size: as this species has larger oocytes, less of them can be stored in the ovary.

451 P. valvatoides displayed an extremely low fecundity, with a maximum of 8 oocytes and no 452 relationship between fecundity and body size was observed. The specific trade-off between 453 size and number of mature oocytes due to individual body-size constraints can explain the low 454 fecundity observed in this species. The very small body size of $P$. valvatoides (below $4 \mathrm{~mm}$ ) is 455 a common characteristic of Skeneidae species. However, P. valvatoides have large and yolky 456 vitellogenic oocytes with a maximum size of $272 \mu \mathrm{m}$, suggesting a lecithotrophic development 457 of the larvae (Haszprunar et al. 2016), similar to most vent gastropods (Lutz et al. 1984; Berg 458 1985; Gustafson and Lutz 1994). While the low fecundity observed in $P$. valvatoides may result 459 in a very weak probability to disperse at large scale and reach a new habitat, this species remains very abundant within vent communities. The simultaneous hermaphroditism observed in this species might contribute to maximizing the number of fertilized individuals, resulting in a larger effective population size (i.e. number of individuals contributing to the next generation). Hence, a large number of reproducing individuals could counteract the low fecundity observed in $P$. valvatoides by ensuring a high retention rate and increasing the number of larvae available for dispersal. This hypothesis requires further investigation and population genetics approaches would bring additional insights in the dispersal of this species.

Recruitment and population structure

The polymodal size-frequency distribution observed within the different samples for both species suggest episodic recruitment events. The discrepancy between continuous gametogenesis and discontinuous recruitment has been previously observed in vent gastropods (Matabos and Thiebaut 2010) and can be related to the occurrence of discrete

473 spawning events and/or post-settlement processes, including mortality and differential 474 growth. In addition, the number of juveniles found in this study is low and many factors can 475 explain this observation. First, the observed fecundity of the two species studied is low, thus 
476

477

478

479

480

481

482

483

484

485

486

487

488

489

490

491

492

493

494

495

496

497

498

499

500

501

502

503

504

505

506

507

each spawning event would supply a small number of larvae, resulting in the settlement of only a few specimens. Secondly, biotic and abiotic factors like competition for space or physical stress on post-settled individuals may play a major role on mortality rates (Kelly and Metaxas 2007). The observed differences in population structure among sampling locations suggest variations in recruitment between different microhabitats, or could be linked to differential mortality and growth rates specific to the habitat. This may be driven by spatial variations in hydrothermal fluid flux, habitat heterogeneity or linked to differences in local diversity that can, in turn, influence biotic interactions. Despite the extremely low fecundity of $P$. valvatoides, the adult population present a high abundance of individuals that can reach up to 4000 individuals.m ${ }^{-2}$ (Husson et al. 2017) in the different locations. Many hypotheses can support this observation. On one hand, the combination of high density of organisms and hermaphroditism might ensure the release of enough fertilized eggs to sustain the local population. On the other hand, it could be possible that the emitted eggs are non-buoyant or directly lay on hard substratum, as observed in other vent gastropods (Gustafson et al. 1991; Fretter and Graham 1994; Yahagi et al. 2017). The direct development of this species within the parental community would result in a high rate of retention within the community. In fact, we noticed the presence of eggs laying on the sulphide substratum among faunal assemblages, which could belong to $P$. valvatoides. Population genetic studies are necessary to better understand the dispersal abilities for this species and determine the level of population retention at the site scale.

\section{Implications for the resilience of vent communities}

A major disturbance at active hydrothermal vents, for example during deep-sea mining operations, would lead to the collapse of the established faunal community. The first step in the colonisation of newly formed low-temperature habitats is marked by the development of free-living microbial communities (Shank et al. 1998). This large microbial production allows the establishment of numerous metazoan species, among which, grazers and scavengers represent the pioneer colonisers (Shank et al. 1998; Mullineaux et al. 2010; Mullineaux et al. 2012; Cuvelier et al. 2018). Then, the main pathway of macrofaunal recolonisation after a large-scale disturbance is the settlement of larvae coming from adjacent areas (regional pool), which results from the coincidence between the timing of disturbance and that of colonist availabilities (Lutz et al. 1984; Pradillon et al. 2005, Mullineaux et al. 2010, 2012). Although 
our knowledge regarding reproductive biology and dispersal capacity of vent species remains scarce, some reproductive features of four dominant macrofaunal species of the Lucky Strike vent field in the Mid-Atlantic Ridge have been investigated (Table 4). These species, which include three gastropods (L. atlanticus, P. midatlantica and $P$. valvatoides) and the polychaete Amphisamytha lutzi, are characterized by early maturity, quasi-continuous gametogenesis and lecithotrophic larval development, which appears to be a common and widespread successful reproductive strategy at vents. Continuous gametogenesis and lecithotrophic development might ensure the continual presence of larvae in the environment and their retention in the surrounding area.

Previous studies have hypothesized the implication of organic falls (e.g. whale falls) as "stepping stones" that represent islands of food resources and suitable habitats for chemosynthetically-fuelled species, and can thus play a connectivity role between vent and seep habitats (Hecker 1985, Smith et al. 1989). Protolira species appear to be able to develop on organic falls and feed on the local microbial production. Indeed, Protolira thorvaldssoni has been found both at vent and seep environments, but also on whale bones, from which the species was originally described (Waren 1996). P. valvatoides has also been recorded on wood substrata deployed in inactive areas on the LS vent field (Alfaro-Lucas et al. in revision). Despite their extremely low fecundity, $P$. valvatoides seems to be able to disperse as larvae, and reach organic substrata, few hundred meters from active vents. This observation is not consistent with our hypotheses of direct development of larvae and high retention rate for this species, and many uncertainties remain regarding their dispersion. It is more likely that the simultaneous hermaphroditism observed in this species represents an advantage over gonochorism in situations in which finding a mate is difficult (Heller et al. 2008). Thus, even in the case of low density of organisms on organic falls, $P$. valvatoides might ensure a relatively good reproductive success and enhance their establishment by maximising the number of offsprings.

To conclude, the two gastropod species considered in the present study exhibit some common phylogenetically constrained reproductive traits, such as early maturity, quasi-continuous gametogenesis and lecithotrophic larval development. This combination of reproductive traits appears to be a widespread attribute among vent invertebrates to ensure the continuity of 
540 larval supply and improve the sustainability of populations in the surrounding environment.

541 However, the two species showed contrasting reproductive features in terms of fecundity, 542 oocyte size and reproductive mode. Indeed, there is an important trade-off between the size 543 and the number of eggs produced by adults that is constrained by morphological and 544 physiological features and is highly dependent on energy availability. In this context, $P$. 545 midatlantica is characterized by the production of smaller mature oocytes counterbalanced 546 by a higher fecundity compared to $P$. valvatoides. This specific strategy may enhance 547 recruitment success by maximizing the number of offsprings but reduce the ability to disperse 548 further because less energy is allocated to a single oocyte. Conversely, $P$. valvatoides produces 549 a very low number of bigger oocytes. For this species, small adult size associated with reduced 550 ovary volume constrain the reproductive output. Despite its low fecundity, P. valvatoides 551 hermaphroditism may be an advantage to enhance the number of fertilized eggs and maintain 552 an important effective population size at the local scale. Therefore, in the context of major 553 disturbance, habitat destruction could lead to a collapse of local populations for both species. 554 Furthermore, despite differences in the reproductive characteristics of the two investigated 555 species, their ability to disperse widely from a preserved area and reach impacted sites seems 556 highly limited by their low fecundity and their dispersal mode (lecithotrophy). However, 557 previous results suggest that $P$. valvatoides might be able to use organic falls as stepping 558 stones to disperse and recolonize an impacted area.

559

560 Finally, this study provides new data on key biological features that can feed bio-physical 561 models of connectivity. In addition, it highlighted that the description of reproductive biology 562 is not sufficient to comprehend all the mechanisms involved in the dispersion and 563 establishment of vent species. Indeed, the role of environmental factors, particularly ocean 564 currents and water column food supply, are essential factors to ensure the settlement of 565 dispersing larvae in newly formed habitats. Therefore, knowledge of biological features and 566 environmental factors associated with population genetics/genomics approaches are needed 567 to better understand the dispersal potential of species inhabiting chemosynthetic-based 568 ecosystems, and the resilience of vent communities (Hilario et al., 2015; Baco et al., 2016). 569 This knowledge is fundamental to define restoration actions that might be implemented to 570 ensure ecosystem sustainability in case of large-scale disturbances induced by mining 571 activities. Thus, the establishment of efficient protected areas with buffer zones and the 
572 deployment of artificial substrata that can act as stepping stones for vent species to recolonize

573 impacted areas, represent important measures to take into consideration.

574

\section{Acknowledgements}

576 We would like to thank the captains and crews of the oceanographic cruises Momarsat 2015, 5772017 and 2018 aboard the vessels N/O Pourquoi pas? and L'Atalante, as well as the ROV 578 Victor6000 team. We are particularly grateful to Pierre-Marie Sarradin and Mathilde Cannat, 579 chief scientists of the cruises who greatly supported our sampling program. We are also 580 sincerely thankful to Sandra Fuchs for sample collection and Julie Tourolle for providing the 581 map as well as all the technicians of the deep sea Ifremer lab. Many thanks to all members of 582 the histological lab of the Norwegian Veterinary Institute and especially to Randi Terland who 583 provided valuable help and assistance with histological processes. We are also grateful to 584 Lucile Durand for the help on imagery acquisition and Florence Pradillon for proofreading the 585 last version of this manuscript. This research was supported by the European H2020 MERCES 586 (Project ID 689518) and by the eCOREF project funded by Equinor (Norway). Julien 587 Marticorena PhD project was funded by Ifremer and Equinor. This project is part of the EMSO588 Azores (http://www.emso-fr.org) regional node and EMSO ERIC Research Infrastructure 589 (http://emso.eu/). ERLL was supported by the European H2020 MERCES (Project ID 689518).

\section{Compliance with Ethical Standards}

591 Fundings This research was supported by the European H2020 MERCES (Project ID 689518) 592 and by the eCOREF project funded by Equinor (Norway). Julien Marticorena PhD project was 593 funded by Ifremer and Equinor. This project is part of the EMSO-Azores (http://www.emso594 fr.org) regional node and EMSO ERIC Research Infrastructure (http://emso.eu/). ERLL was 595 supported by the European H2020 MERCES (Project ID 689518).

596 Conflicts of interest The authors declare that they have no conflict of interest.

597 Ethics approval All applicable international, national, and/or institutional guidelines for 598 sampling were followed in the current study.

599 Consent to participate Not applicable 
600 Consent for publication The Author hereby consents to publication of the work in any and 601 all Springer publications. The Author warrants that the work has not been published in any 602 form except as a preprint that the work is not being concurrently submitted to and is not 603 under consideration by another publisher.

\section{Availability of data and material Not applicable}

605 Code availability Not applicable

606 Authors' contributions JM, MM, JS and ERLL conceived the ideas and designed the 607 methodology. JM, MM and JS collected the data and JM processed and analysed the data. $608 \mathrm{JM}$ wrote the first draft of the manuscript and all authors commented on previous versions 609 of the manuscript. All authors read and approved the final manuscript.

\section{Tables}

611 Table 1. Summary of vent sites and stations, time of sampling, number of individuals and 612 shell size range of all individuals of the two species used for histological analyses in this 613 study. Mean and standard deviation of temperature measured on each quadrat during a 614 year are also presented.

\begin{tabular}{|c|c|c|c|c|c|c|}
\hline Species & Edifice & Station & Date & $\begin{array}{l}\text { Number of } \\
\text { individuals }\end{array}$ & $\begin{array}{l}\text { Shell length } \\
\text { range }(\mathrm{mm})\end{array}$ & $\begin{array}{l}\text { Temperature }\left({ }^{\circ} \mathrm{C}\right) \\
(\text { mean } \pm \mathrm{sd})\end{array}$ \\
\hline \multirow[t]{8}{*}{ Prototolira valvatoides } & Montségur & $\mathrm{C} 1 \mathrm{a}$ & July 2017 & 5 & $1.7-2.6$ & $5.7 \pm 0.26$ \\
\hline & & & August 2018 & 5 & $1.9-2.7$ & \\
\hline & & C1acg & July 2017 & 4 & $1.9-2.8$ & $5.1 \pm 0.08$ \\
\hline & & & August 2018 & 12 & $1.8-3.1$ & \\
\hline & & C1bcg & August 2018 & 7 & $1.9-2.6$ & $5.3 \pm 0.38$ \\
\hline & & $\mathrm{C} 2 \mathrm{a}$ & July 2017 & 3 & $1.7-2.7$ & $6.6 \pm 0.92$ \\
\hline & & R1 & August 2018 & 4 & $1.8-2.9$ & $8.3 \pm 1.13$ \\
\hline & Eiffel Tower & ET & April 2015 & 18 & $1.8-3.5$ & $5.3 \pm 0.36$ \\
\hline \multirow[t]{8}{*}{ Pseudorimula midatlantica } & Montségur & $\mathrm{C} 1 \mathrm{a}$ & July 2017 & 1 & 4.7 & $5.7 \pm 0.26$ \\
\hline & & C1acg & August 2018 & 10 & $4-6.5$ & $5.1 \pm 0.08$ \\
\hline & & $\mathrm{C} 1 \mathrm{~b}$ & August 2018 & 3 & $3.6-5$ & $5.1 \pm 0.3$ \\
\hline & & C1bcg & August 2018 & 5 & $3.3-5.7$ & $5.3 \pm 0.38$ \\
\hline & & $\mathrm{C} 2 \mathrm{a}$ & July 2017 & 5 & $4.2-5.9$ & $6.6 \pm 0.92$ \\
\hline & & $\mathrm{C} 2 \mathrm{bcg}$ & July 2017 & 2 & $4.6-5.3$ & $5.3 \pm 0.42$ \\
\hline & & $\mathrm{R} 1$ & July 2018 & 3 & $3.9-6.7$ & $8.3 \pm 1.13$ \\
\hline & Eiffel Tower & ET & April 2015 & 5 & $4.1-5.8$ & $5.3 \pm 0.36$ \\
\hline
\end{tabular}

616 Table 2. Matrix of $p$-value of the Nemenyi and Dunn multiple range test used to compare the 617 shell length distribution of Protolira valvatoides (up-right) and Pseudorimula midatlantica 618 (down-left) among the different locations. ns = not significant ; $*_{p}<0.05 ; *^{*} p<0.01 ;$ 
$* * * p<0.001$.

\begin{tabular}{|c|c|c|c|c|c|c|c|}
\hline Quadrat & $\mathrm{C} 1 \mathrm{a}$ & C1acg & C1b & C1bcg & $\mathrm{C} 2 \mathrm{a}$ & $\mathrm{C} 2 \mathrm{bcg}$ & R1 \\
\hline $\mathrm{C} 1 \mathrm{a}$ & & $* * *$ & . & $*$ & $* *$ & . & $*$ \\
\hline C1acg & $* * *$ & & . & $* * *$ & ns & . & ns \\
\hline $\mathrm{C} 1 \mathrm{~b}$ & $* * *$ & ns & & . & . & . & . \\
\hline C1bcg & $*$ & $* * *$ & $*$ & & $* * *$ & . & $* *$ \\
\hline $\mathrm{C} 2 \mathrm{a}$ & $* * *$ & $* *$ & ns & $* * *$ & & . & $*$ \\
\hline $\mathrm{C} 2 \mathrm{bcg}$ & $* *$ & $*$ & ns & ns & $* * *$ & & . \\
\hline $\mathrm{R} 1$ & $* * *$ & ns & ns & $* * *$ & $* * *$ & $* * *$ & \\
\hline
\end{tabular}

620 
621 Table 3. Summary of known reproductive traits of hydrothermal vent limpets from the

622 Lepetodrilidae family. JDFR: Juan de Fuca Ridge, EPR: East Pacific Rise, MAR: Mid-Atlantic

623 Ridge.

\begin{tabular}{|c|c|c|c|c|c|c|}
\hline Species & Date & Location & $\begin{array}{l}\text { Maximum size } \\
\text { of vitellogenic } \\
\text { oocytes }(\mu \mathrm{m})\end{array}$ & $\begin{array}{l}\text { Onset of } \\
\text { vitellogenesis } \\
(\mu \mathrm{m})\end{array}$ & $\begin{array}{l}\text { Instantaneous fecundity } \\
\text { (Mean } \pm \text { SD) [Max] }\end{array}$ & References \\
\hline \multicolumn{7}{|l|}{ Lepetodrilus } \\
\hline fucensis & Jul. 2001 & JFDR & 110 & $35-45$ & $125.7 \pm 121.4[5149]$ & Kelly and Metaxas (2007) \\
\hline & Jul.-Sept. 1984 & & 140 & & & Fretter (1988) \\
\hline \multicolumn{7}{|l|}{ Lepetodrilus } \\
\hline pustulosus & Mar. 1984 & EPR & 120 & & & Fretter (1988) \\
\hline & Dec. 2001 & & 84 & $30-35$ & $53.9 \pm 42.3[850]$ & Pendlebury (2005); Tyler et al. (2008) \\
\hline & Apr.-May 1979 & & 104 & & & Berg (1985) \\
\hline \multicolumn{7}{|l|}{ Lepetodrilus } \\
\hline elevatus & Dec. 2001 & EPR & 84 & $30-35$ & [1800] & Pendlebury (2005); Tyler et al. (2008) \\
\hline & Apr.-May 1979 & & 95 & & & Berg (1985) \\
\hline Lepetodrilus. & & & & & & \\
\hline $\begin{array}{l}\text { ovalis } \\
\text { Lepetodrilus. }\end{array}$ & Dec. 2001 & EPR & 87 & $30-35$ & $27.9 \pm 32.6[400]$ & Pendlebury (2005); Tyler et al. (2008) \\
\hline $\begin{array}{l}\text { cristatus } \\
\text { Lepetodrilus }\end{array}$ & Mar.1984 & EPR & 150 & $30-35$ & & Fretter (1988) \\
\hline $\begin{array}{l}\text { tevnianus } \\
\text { Lepetodrilus }\end{array}$ & Dec.2006 & EPR & 210 & $35-40$ & & Bayer et al. (2011) \\
\hline $\begin{array}{l}\text { atlanticus } \\
\text { seudorimula. }\end{array}$ & Mar.-Apr. 2001 & MAR & 92 & $35-40$ & $37.2 \pm 24.1[300]$ & Pendlebury (2005); Tyler et al. (2008) \\
\hline midatlantica & Apr. 2015 & MAR & 155 & $40-50$ & $187 \pm 44[327]$ & This study \\
\hline & Jul. 2017 & & 175 & & & This study \\
\hline 624 & Aug. 2018 & & 176 & & & This study \\
\hline
\end{tabular}


625 Table 4. Summary of known reproductive traits of dominant species of the Lucky Strike vent

626 field. *Fecundity refers to the total number of oocytes within a female regardless of the

627 development stage while it refers to the number of vitellogenic oocytes for the other studies.

\begin{tabular}{|c|c|c|c|c|c|c|}
\hline Species & $\begin{array}{l}\text { Reproductive } \\
\text { strategy }\end{array}$ & $\begin{array}{l}\text { Size of vitellogenic } \\
\text { oocytes }(\mu \mathrm{m})\end{array}$ & Fecundity & Larval devlopment & Seasonality & References \\
\hline Bathymodiolus azoricus & Gonochoric & $70-80$ & No data & Planktotrophic & Seasonal & $\begin{array}{l}\text { Colaço et al. (2006) } \\
\text { Dixon et al. (2006) }\end{array}$ \\
\hline Branchipolynoe seepensis & Gonochoric & $250-500$ & $100-300$ & Lecithotrophic & Quasi-continuous & Jollivet et al. (2006) \\
\hline Amphisamytha lutzi & Gonochoric & $150-190$ & $>2500^{*}$ & Lecithotrophic & Quasi-continuous & Blake et al. (2005) \\
\hline Lepetodrillus atlanticus & Gonochoric & $50-92$ & $95-300$ & Lecithotrophic & Quasi-continuous & Tyler et al. (2008) \\
\hline Pseudorimula midatlantica & Gonochoric & $80-176$ & $107-327$ & Lecithotrophic & Quasi-continuous & This study \\
\hline Protolira valvatoides & Hermaphrodite & $120-272$ & $4-8$ & Lecithotrophic & Quasi-continuous & This study \\
\hline
\end{tabular}

\section{Figure legends}

630

631 Fig.1 A. Location of the Lucky Strike vent field on the Mid-Atlantic ridge, south of the Azores.

632 B. The $1 \mathrm{~km}^{2}$ LS vent field with the Montségur and Eiffel Tower edifices on the south-east. C.

633 Location of the different sampling locations on and around the Montségur edifice.

634

635 Fig.2 Morphology of reproductive structures of Protolira valvatoides (left) and Pseudorimula 636 midatlantica (right). A. Dorsal view of $P$. valvatoides soft body. B. Ventral view of $P$. 637 midatlantica soft body. C. General view of a transversal section of $P$. valvatoides. D. General 638 view of a transversal section of a $P$. midatlantica female. E. Detailed view of $P$. valvatoides 639 ovary. F. Detailed view of $P$. midatlantica ovary. G. Detailed of $P$. valvatoides testis. H. Detailed 640 view of P. midatlantica testis. Abbreviations: ct: ctenidium; dg: digestive glands; f: foot, ov: 641 ovary; oo: oogonia; pvo: previtellogenic oocyte; s: snout; st: stomach; spd: spermatid; spg: 642 spermatogonia; spz: spermatozoa; $t$ : testis; vo: vitellogenic oocytes. Scale bars: $A$ and C=1mm; $643 B$ and $D=2 m m ; E$, F and $H=200 \mu m ; G=50 \mu m$.

644

645 Fig.3 Mean oocyte size-frequency histograms (mean \pm SD) of pooled individuals of Protolira 646 valvatoides for each quadrat. Colors: Grey bars represent previtellogenic oocytes and yellow 647 bars represent vitellogenic oocytes. Abbreviations: $N$, number of individuals; $n$, number of 648 oocytes measured. 
650 Fig.4 Mean oocyte size-frequency histograms (mean \pm SD) of pooled individuals of 651 Pseudorimula midatlantica for each quadrat. Colors: Grey bars represent previtellogenic 652 oocytes and yellow bars represent vitellogenic oocytes. Abbreviations: $N$, number of 653 individuals; $n$, number of oocytes measured.

654

655 Fig.5 Box-plot of the oocyte size-distribution of the two studied gastropods Protolira 656 valvatoides (left) and Pseudorimula midatlantica (right) among the different samples. The 657 mean oocyte size is represented by a black diamond A. Boxplot showing the oocyte-size 658 distribution of each individual of $P$. valvatoides among the different samples. B. Boxplot 659 showing the oocyte-size distribution of each individual of $P$. midatlantica among the different 660 samples. C. Boxplot showing the oocyte-size distribution of pooled individuals of $P$. 661 valvatoides among the different samples. D. Boxplot showing the oocyte-size distribution of 662 pooled individuals of $P$. midatlantica among the different samples. Abbreviations: $N$, number 663 of individuals; $n$, number of oocytes measured. Multisample comparisons were performed 664 using the Nemenyi and Dunn test; homogeneous groups share the same letter.

665

666 Fig.6 Relationship between animal shell length and proportion of vitellogenic oocytes for each 667 specimen of A. Protolira valvatoides and B. Pseudorimula midatlantica among the different 668 samples.

669 Fig.7 Size-frequency distribution of shell length of A. Protolira valvatoides and B. Pseudorimula 670 midatlantica among the different samples. Abbreviations: $n$, number of individuals measured.

671

672

673

674

675

676 


\section{Supplementary material}

678 Table S1. Results of Kruskal-Wallis multisample tests and the Nemenyi and Dunn multiple

679 range tests comparing oocyte size distributions between individuals of the two gastropod

680 species within each sample.

\begin{tabular}{|c|c|c|c|c|c|c|}
\hline Species & Edifice & Station & Date & $\begin{array}{l}\text { Number of } \\
\text { individuals }\end{array}$ & Kruskal-Wallis multisample test & Nemenyi and Dunn multiple range test \\
\hline \multirow[t]{8}{*}{ Prototolira valvatoides } & Montségur & C1a & July 2017 & 5 & $H=29.69, \mathrm{df}=4, \mathrm{P}<0.001$ & $1 / 5$ different \\
\hline & & & August 2018 & 5 & $H=7.87, d f=4, P<0.05$ & $2 / 5$ different \\
\hline & & C1acg & July 2017 & 4 & $H=6.25, d f=3, P<0.05$ & $1 / 4$ different \\
\hline & & & August 2018 & 12 & $H=153.72, d f=11, P<0.001$ & $3 / 12$ different \\
\hline & & C1bcg & August 2018 & 7 & $H=70.49, d f=6, P<0.001$ & 2/7 different \\
\hline & & $\mathrm{C} 2 \mathrm{a}$ & July 2017 & 3 & $H=1.23, d f=2, P>0.05$ & - \\
\hline & & R1 & August 2018 & 4 & $H=13.12, d f=4, P<0.05$ & $1 / 4$ different \\
\hline & Eiffel Tower & ET & April 2015 & 18 & $H=107.51, d f=17, P<0.001$ & 2/18 different \\
\hline \multirow[t]{8}{*}{ Pseudorimula midatlantica } & Montséegur & C1a & July 2017 & 1 & - & - \\
\hline & & C1acg & August 2018 & 10 & $H=23.54, d f=9, P<0.05$ & $2 / 10$ different \\
\hline & & $\mathrm{C} 1 \mathrm{~b}$ & August 2018 & 3 & $\mathrm{H}=1.89, \mathrm{df}=2, \mathrm{P}>0.05$ & - \\
\hline & & C1bcg & August 2018 & 5 & $H=8.66, d f=4, P>0.05$ & - \\
\hline & & $\mathrm{C} 2 \mathrm{a}$ & July 2017 & 5 & $H=10.47, d f=4, P<0.01$ & $1 / 5$ different \\
\hline & & $\mathrm{C} 2 \mathrm{bcg}$ & July 2017 & 2 & $\mathrm{H}=8.22, \mathrm{df}=1, \mathrm{P}<0.05$ & $1 / 2$ different \\
\hline & & $\mathrm{R} 1$ & July 2017 & 3 & $H=63.06, d f=2, P<0.001$ & $1 / 3$ different \\
\hline & Eiffel Tower & ET & April 2015 & 5 & $H=40.10, d f=4, P<0.001$ & $2 / 5$ different \\
\hline
\end{tabular}

681

682 Fig.S1 Mean oocyte size-frequency histograms (mean \pm SD) of pooled individuals of Protolira

683 valvatoides for each sampling period. Colors: Grey bars represent previtellogenic oocytes and

684 yellow bars represent vitellogenic oocytes. Abbreviations: $N$, number of individuals; $n$, number

685 of oocytes measured.

686 Fig.S2 Mean oocyte size-frequency histograms (mean \pm SD) of pooled individuals of 687 Pseudorimula midatlantica for each sampling period. Colors: Grey bars represent 688 previtellogenic oocytes and yellow bars represent vitellogenic oocytes. Abbreviations: $N$, 689 number of individuals; $n$, number of oocytes measured.

690

691 DOI of the cruises involved

692 SARRADIN Pierre-Marie, CANNAT Mathilde (2015) MOMARSAT2015 cruise, RV Pourquoi pas 
SARRADIN Pierre-Marie, CANNAT Mathilde (2017) MOMARSAT2017 cruise, RV Pourquoi pas ?, https://doi.org/10.17600/17000500

CANNAT Mathilde (2018) MOMARSAT2018 cruise, RV L'Atalante, https://doi.org/10.17600/18000514

\section{References}

Adams, D.K., S.M. Arellano, and B. Govenar. (2012). Larval dispersal: Vent life in the water column. Oceanography 25(1): 256-268. doi:10.5670/oceanog.2012.24.

Baco AR, Etter RJ, Ribeiro PA, Heyden S von der, Beerli P, Kinlan BP (2016) A synthesis of genetic connectivity in deep-sea fauna and implications for marine reserve design. Mol Ecol 25: 3276-3298. doi: 10.1111/mec.13689

Bates AE (2006) Population and feeding characteristics of hydrothermal vent gastropods along environmental gradients with a focus on bacterial symbiosis hosted by Lepetodrilus fucensis (Vetigastropoda). PhD Thesis

Bayer SR, Mullineaux LS, Waller RG, Solow AR (2011) Reproductive traits of pioneer gastropod species colonizing deep-sea hydrothermal vents after an eruption. Mar Biol 158: 181-192. doi: $10.1007 / \mathrm{s} 00227-010-1550-1$

Blake EA, Dover CLV (2005) The reproductive biology of Amathys lutzi, an ampharetid polychaete from hydrothermal vents on the Mid-Atlantic Ridge. Invertebr Biol 124: 254264. doi: 10.1111/i.1744-7410.2005.00022.x

Berg, C. J. (1985) Reproductive strategies of mollusks from abyssal hydrothermal vent communities. Bull Biol Soc Wash 6: 185-197

Boschen RE, Rowden AA, Clark MR, Pallentin A, Gardner JPA (2016) Seafloor massive sulfide deposits support unique megafaunal assemblages: Implications for seabed mining and conservation. Mar Environ Res 115: 78-88. doi: 10.1016/j.marenvres.2016.02.005

Bouchet, P. and Warén, A. (1991) Ifremeria nautilei, a new gastropod from hydrothermal vents, probably associated with symbiotic bacteria. Cr Acad Sci lii-Vie 312, 495-501.

Breusing C, Biastoch A, Drews A, Metaxas A, Jollivet D, Vrijenhoek RC, Bayer T, Melzner F, Sayavedra L, Petersen JM, Dubilier N, Schilhabel MB, Rosenstiel P, Reusch TBH (2016) Biophysical and Population Genetic Models Predict the Presence of "Phantom" Stepping Stones Connecting Mid-Atlantic Ridge Vent Ecosystems. Curr Biol 26: 2257-2267. doi: 10.1016/i.cub.2016.06.062

Bridges TS, Levin LA, Cabrera D, Plaia G (1994) Effects of sediment amended with sewage, algae, or hydrocarbons on growth and reproduction in two opportunistic polychaetes. $J$ Exp Mar Biol Ecol 177: 99-119. doi: 10.1016/0022-0981(94)90146-5

Carpenter S, Walker B, Anderies JM, Abel N (2001) From Metaphor to Measurement: Resilience of What to What? Ecosystems 4:765-781. doi: 10.1007/s10021-001-0045-9

Clark, M.R., Smith, S., (2013) Environ Manag Consid. In: Deep Sea Minerals: Manganese Nodules, A Physical, Biological, Environmental and Technical Review, SPC1B, pp. 27e41

Colaço A, Martins I, Laranjo M, Pires L, Leal C, Prieto C, Costa V, Lopes H, Rosa D, Dando PR, Serrão-Santos R (2006) Annual spawning of the hydrothermal vent mussel, Bathymodiolus azoricus, under controlled aquarium, conditions at atmospheric pressure. J Exp Mar Biol Ecol 333: 166-171. doi: 10.1016/i.jembe.2005.12.005 
Colaço A, Desbruyères D, Guezennec J (2007) Polar lipid fatty acids as indicators of trophic associations in a deep-sea vent system community. Mar Ecol 28: 15-24. doi: 10.1111/j.1439-0485.2006.00123.x

Connell SD, Ghedini G (2015) Resisting regime-shifts: the stabilising effect of compensatory processes. Trends Ecol Evol 30: 513-515. doi: 10.1016/i.tree.2015.06.014

Cumming GS, Olsson P, Chapin FS, Holling CS (2013) Resilience, experimentation, and scale mismatches in social-ecological landscapes. Landscape Ecol 28: 1139-1150. doi: 10.1007/s10980-012-9725-4

Cuvelier D, Beesau J, Ivanenko VN, Zeppilli D, Sarradin P-M, Sarrazin J (2014) First insights into macro- and meiofaunal colonisation patterns on paired wood/slate substrata at Atlantic deep-sea hydrothermal vents. Deep-Sea Res Pt I 87: 70-81. doi: 10.1016/j.dsr.2014.02.008

Cuvelier D, Gollner S, Jones DOB, Kaiser S, Arbizu PM, Menzel L, Mestre NC, Morato T, Pham C, Pradillon F, Purser A, Raschka U, Sarrazin J, Simon-Lledó E, Stewart IM, Stuckas H, Sweetman AK, Colaço A (2018) Potential Mitigation and Restoration Actions in Ecosystems Impacted by Seabed Mining. Front Mar Sci. doi: 10.3389/fmars.2018.00467

De Busserolles F, Sarrazin J, Gauthier O, Gélinas Y, Fabri MC, Sarradin PM, Desbruyères D (2009) Are spatial variations in the diets of hydrothermal fauna linked to local environmental conditions? Deep-Sea Res Pt II 56:1649-1664. doi: 10.1016/i.dsr2.2009.05.011

DeFreese DE, Clark KB (1983) Analysis of reproductive energetics of Florida Opisthobranchia (Mollusca: Gastropoda). Int J Inver Rep 6: 1-10. doi: 10.1080/01651269.1983.10510018

Desbruyères $D$, Biscoito $M$, Caprais J-C, Colaço $A$, Comtet $T$, Crassous $P$, Fouquet $Y$, Khripounoff A, Le Bris N, Olu K, Riso R, Sarradin P-M, Segonzac M, Vangriesheim A (2001) Variations in deep-sea hydrothermal vent communities on the Mid-Atlantic Ridge near the Azores plateau. Deep-Sea Res Pt I 48: 1325-1346. doi: 10.1016/S09670637(00)00083-2

Desbruyères $D$, Segonzac $M$, Bright $M$, Biologiezentrum OL, Desbruyeres $D$, Segonzac $M$, Bright M (2006) Handbook of deep-sea hydrothermal vent fauna, 2nd completely rev. ed. / editors, Daniel Desbruyères, Michel Segonzac and Monika Bright. Linz, Austria : Land Oberösterreich, Biologiezentrum der Oberösterreichische Landesmuseen Dixon DR, Lowe DM, Miller PI, Villemin GR, Colaço A, Serrão-Santos R, Dixon LRJ (2006) Evidence of seasonal reproduction in the Atlantic vent mussel Bathymodiolus azoricus, and an apparent link with the timing of photosynthetic primary production. J of the J Mar Biol Assoc UK 86: 1363-1371. doi: 10.1017/S0025315406014391

Eckelbarger KJ, Eckelbarger KJ (1994) Diversity Of Metazoan Ovaries And Vitellogenic Mechanisms - Implications For Life history Theory. P Biol Soc Wash 107: 193-218.

Eckelbarger KJ, Watling L (1995) Role of Phylogenetic Constraints in Determining Reproductive Patterns in Deep-Sea Invertebrates. Inver Biol 114:256-269. doi: $10.2307 / 3226880$

Fretter V (1988) New archaeogastropod limpets from hydrothermal vents; Superfamily Lepetodrilacea. II. Anatomy. Philos T Roy Soc B 319:33-82. doi: 10.1098/rstb.1988.0032

Fretter V (1989) The anatomy of some new archaeogastropod limpets (Superfamily Peltospiracea) from hydrothermal vents. J Zool 218: 123-169. doi: 10.1111/i.14697998.1989.tb02530.x

Fretter V, Graham A (1994) British prosobranch molluscs. Their functional anatomy and ecology. Publ Brit Ray Soc, No. 144 
802

803

804

805

806

807

808

809

810

811

812

813

814

815

816

817

818

819

820

821

822

823

824

825

826

827

Gabe M (1968) Techniques histologiques. Masson

Gage JD, Tyler PA (1991) Deep-Sea Biology: A Natural History of Organisms at the Deep-Sea Floor. Camb U Pr

Galkin SV, Goroslavskaya El (2010) Bottom fauna associated with Bathymodiolus azoricus (Mytilidae) mussel beds in the hydrothermal fields of the Mid-Atlantic Ridge. Oceanology 50: 51-60. doi: 10.1134/S0001437010010066

Gladstone-Gallagher RV, Pilditch CA, Stephenson F, Thrush SF (2019) Linking Traits across Ecological Scales Determines Functional Resilience. Trends Ecol Evol 34: 1080-1091. doi: 10.1016/i.tree.2019.07.010

Gollner S, Govenar B, Arbizu PM, Mills S, Le Bris N, Weinbauer M, Shank TM, Bright M (2015) Differences in recovery between deep-sea hydrothermal vent and vent-proximate communities after a volcanic eruption. Deep-Sea Res Pt I 106: 167-182. doi: 10.1016/j.dsr.2015.10.008

Gollner S, Kaiser S, Menzel L, Jones DOB, Brown A, Mestre NC, van Oevelen D, Menot L, Colaço A, Canals M, Cuvelier D, Durden JM, Gebruk A, Egho GA, Haeckel M, Marcon Y, Mevenkamp L, Morato T, Pham CK, Purser A, Sanchez-Vidal A, Vanreusel A, Vink A, Martinez Arbizu P (2017) Resilience of benthic deep-sea fauna to mining activities. Mar Environ Res 129:76-101. doi: 10.1016/i.marenvres.2017.04.010

Guezennec J, Ortega-Morales O, Raguenes G, Geesey G (1998) Bacterial colonization of artificial substrate in the vicinity of deep-sea hydrothermal vents. FEMS Microbiol Ecol 26:89-99. doi: 10.1016/S0168-6496(98)00022-1

Gustafson RG, Littlewood DTJ, Lutz RA (1991) Gastropod Egg Capsules and Their Contents From Deep-Sea Hydrothermal Vent Environments. Biol Bull 180: 34-55. doi: $10.2307 / 1542427$

Gustafson RG and Lutz RA (1994). Molluscan life history traits at deep sea hydrothermal vents and cold methane/ sulfide seeps. In Reproduction, larval biology, and recruitment in deep-sea benthos (ed. C.M. Young and K. Eckelbarger), pp.76-97. NewYork: Columb U $\operatorname{Pr}$

Haszprunar G (1989) New slit-limpets (Scissurellacea and Fissurellacea) from hydrothermal vents. Part 2. Anatomy and relationships. Contrib. sci. (Los Angel. Calif.) 408: 1-17.

Haszprunar G, Kunze T, Brückner M, Heß M (2016) Towards a sound definition of Skeneidae (Mollusca, Vetigastropoda): 3D interactive anatomy of the type species, Skenea serpuloides (Montagu, 1808) and comments on related taxa. Org Divers Evol 16:577595. doi: $10.1007 / \mathrm{s} 13127-015-0260-4$

Hecker B (1985) Fauna from a cold sulfur-seep in the Gulf of Mexico: comparison with hydrothermal vent communities and evolutionary implications. Bull Biol Soc Wash 6: 465-473.

Hein JR, Mizell K, Koschinsky A, Conrad TA (2013) Deep-ocean mineral deposits as a source of critical metals for high- and green-technology applications: Comparison with land-based resources. Ore Geol Rev 51: 1-14. doi: 10.1016/j.oregeorev.2012.12.001

Heller J (1993) Hermaphroditism in molluscs. Biol J Linn Soc 48:19-42. doi: 10.1111/i.10958312.1993.tb00874.x

Hilário A, Young CM, Tyler PA (2005) Sperm Storage, Internal Fertilization, and Embryonic Dispersal in Vent and Seep Tubeworms (Polychaeta: Siboglinidae: Vestimentifera). Biol Bull 208: 20-28. doi: 10.2307/3593097 
Hilário A, Metaxas A, Gaudron SM, Howell KL, Mercier A, Mestre NC, Ross RE, Thurnherr AM, Young C (2015) Estimating dispersal distance in the deep sea: challenges and applications to marine reserves. Front Mar Sci. doi: 10.3389/fmars.2015.00006

Honkoop PJC and Van der Meer J (1997). Reproductive output of Macoma balthica populations in relation to winter-temperature and intertidalheight mediated changes of body mass. Mar Ecol Prog. Ser. 149, 155-162.

Husson B, Sarradin P-M, Zeppilli D, Sarrazin J (2017) Picturing thermal niches and biomass of hydrothermal vent species. Deep-Sea Res Pt II 137: 6-25. doi:

10.1016/i.dsr2.2016.05.028

Ingrisch J, Bahn M (2018) Towards a Comparable Quantification of Resilience. Trends Ecol Evol 33: 251-259. doi: 10.1016/i.tree.2018.01.013

Jaeckle W (1995) Variation in the Size, Energy Content, and Biochemical Composition of Invertebrate Eggs: Correlates to the Mode of Larval Development. pp. 49-77 in Ecol of Mar Inver Larv, L. Mc Edward, ed. CRC Press, Boca Raton, FL

Jollivet $D$, Empis A, Baker MC, Hourdez $S$, Comtet $T$, Jouin-Toulmond C, Desbruyères $D$, Tyler PA (2000) Reproductive biology, sexual dimorphism, and population structure of the deep sea hydrothermal vent scale-worm, Branchipolynoe seepensis (Polychaeta: Polynoidae). J Mar Biol Ass UK 80: 55-68. doi: 10.1017/S0025315499001563

Kelly NE, Metaxas A (2007) Influence of habitat on the reproductive biology of the deep-sea hydrothermal vent limpet Lepetodrilus fucensis (Vetigastropoda: Mollusca) from the Northeast Pacific. Mar Biol 151:649-662. doi: 10.1007/s00227-006-0505-z

Laming SR, Gaudron SM, Duperron S (2018) Lifecycle Ecology of Deep-Sea Chemosymbiotic Mussels: A Review. Front Mar Sci. doi: 10.3389/fmars.2018.00282

Levin LA., Bridges TS. (1995) Pattern and diversity in reproduction and development. In: McFdward LR, ed. Ecol Mar Inver Larv. Boca Raton, Florida: CRC Press, 1-48.

Levin LA (2006) Recent progress in understanding larval dispersal: new directions and digressions. Integr Comp Biol 46: 282-297. doi: 10.1093/icb/icj024

Levin LA, Mengerink K, Gjerde KM, Rowden AA, Van Dover CL, Clark MR, Ramirez-Llodra E, Currie B, Smith CR, Sato KN, Gallo N, Sweetman AK, Lily H, Armstrong CW, Brider J (2016) Defining "serious harm" to the marine environment in the context of deepseabed mining. Mar Pol 74: 245-259. doi: 10.1016/i.marpol.2016.09.032

Lutz RA, Jablonski D, Turner RD (1984) Larval Development and Dispersal at Deep-Sea Hydrothermal Vents. Science 226: 1451-1454. doi: 10.1126/science.226.4681.1451

Lutz RA, Bouchet P, Jablonski D, Turner RD, and Warén A (1986), Larval ecology of mollusks at deep-sea hydrothermal vents, Am Malacol Bull 4, 49-54,

Mac Donald P, Du with contributions from J (2018) mixdist: Finite Mixture Distribution Models.

Martell KA, Tunnicliffe V, Macdonald IR (2002) Biological features of a buccinid whelk (Gastropoda, Neogastropoda) at the Endeavour Vent-field of Juand de Fuca Ridge, Northest Pacific. J Molluscan Stud 68:45-53. doi: 10.1093/mollus/68.1.45

Matabos M, Thiebaut E (2010) Reproductive biology of three hydrothermal vent peltospirid gastropods (Nodopelta heminoda, N. subnoda and Peltospira operculata) associated with Pompeii worms on the East Pacific Rise. J Molluscan Stud 76:257-266. doi: 10.1093/mollus/eyq008

Matabos M, Cuvelier D, Brouard J, Shillito B, Ravaux J, Zbinden M, Barthelemy D, Sarradin PM, Sarrazin J (2015) Behavioural study of two hydrothermal crustacean decapods: 
881

882

883

884

885

886

887

888

889

890

891

892

893

894

895

896

897

898

899

900

901

902

903

904

905

906

907

908

909

910

911

912

913

914

915

916

917

918

919

Mirocaris fortunata and Segonzacia mesatlantica, from the Lucky Strike vent field (MidAtlantic Ridge). Deep-Sea Res Pt II 121: 146-158. doi: 10.1016/i.dsr2.2015.04.008

McHugh D (1995) Unusual Sperm Morphology in a Deep-Sea Hydrothermal-Vent Polychaete, Paralvinella pandorae (Alvinellidae). Inver Biol 114: 161-168. doi: 10.2307/3226888

McHugh D, Tunnicliffe V (1994) Ecology and reproductive biology of the hydrothermal vent polychaete Amphisamytha galapagensis (Ampharetidae). Mar Ecol Progr Ser 106:111120. doi: $10.3354 /$ meps106111

McLean JH, Haszprunar G (1987) Pyropeltidae, a new family of cocculiniform limpets from hydrothermal vents. Veliger 30:196-205

McLean JH (1992) A new species of Pseudorimula (Fissurellacea: Clypeosectidae) from hydrothermal vents of the Mid-Atlantic Ridge. Nautilus 106(3): 115-118

Metaxas A, Saunders M (2009) Quantifying the "Bio-" Components in Biophysical Models of Larval Transport in Marine Benthic Invertebrates: Advances and Pitfalls. Biol Bull 216: 257-272. doi: 10.1086/BBLv216n3p257

Mullineaux LS, Adams DK, Mills SW, Beaulieu SE (2010) Larvae from afar colonize deep-sea hydrothermal vents after a catastrophic eruption. PNAS 107:7829-7834. doi: 10.1073/pnas.0913187107

Mullineaux LS, Bris NL, Mills SW, Henri P, Bayer SR, Secrist RG, Siu N (2012) Detecting the Influence of Initial Pioneers on Succession at Deep-Sea Vents. PLOS ONE 7:e50015. doi: 10.1371/journal.pone.0050015

Nakamura M, Watanabe H, Sasaki T, Ishibashi J, Fujikura K, Mitarai S (2014) Life history traits of Lepetodrilus nux in the Okinawa Trough, based upon gametogenesis, shell size, and genetic variability. Mar Ecol Progr Ser 505:119-130. doi: 10.3354/meps10779

Oliver TH, Heard MS, Isaac NJB, Roy DB, Procter D, Eigenbrod F, Freckleton R, Hector A, Orme CDL, Petchey OL, Proença V, Raffaelli D, Suttle KB, Mace GM, Martín-López B, Woodcock BA, Bullock JM (2015) Biodiversity and Resilience of Ecosystem Functions. Trends Ecol Evol 30:673-684. doi: 10.1016/i.tree.2015.08.009

Portail M, Brandily C, Cathalot C, Colaço A, Gélinas Y, Husson B, Sarradin P-M, Sarrazin J (2018) Food-web complexity across hydrothermal vents on the Azores triple junction. Deep-Sea Res Pt I 131:101-120. doi: 10.1016/i.dsr.2017.11.010

Pradillon F, Shillito B, Young CM, Gaill F (2001) Developmental arrest in vent worm embryos. Nature 413:698-699. doi: 10.1038/35099674

Pradillon F, Bris NL, Shillito B, Young CM, Gaill F (2005) Influence of environmental conditions on early development of the hydrothermal vent polychaete Alvinella pompejana. J Exp Biol 208:1551-1561. doi: 10.1242/jeb.01567

Pendlebury S (2005) Ecology of hydrothermal vent gastropods. PhD thesis. School of Ocean and Eart Sciences, Southampton, 148 pp.

Ramirez-Llodra E (2002) Fecundity and life-history strategies in marine invertebrates. In: Adv Mar Biol pp 87-170

Ramirez-Llodra E, Tyler PA, Baker MC, Bergstad OA, Clark MR, Escobar E, Levin LA, Menot L, Rowden AA, Smith CR, Dover CLV (2011) Man and the Last Great Wilderness: Human Impact on the Deep Sea. PLOS ONE 6:e22588. doi: 10.1371/journal.pone.0022588

Ramirez-Llodra R, Tyler PA, Copley JTP (2000) Reproductive biology of three caridean shrimp, Rimicaris exoculata, Chorocaris chacei and Mirocaris fortunata (Caridea: Decapoda), from hydrothermal vents. J Mar Biol Ass U K 80:473-484. doi: $10.1017 / \mathrm{S} 0025315400002174$ 
951

952

953

954

955

956

957

958

959

960

961

962

963

964

965

966

R Studio Team (2016). RStudio: Integrated Development Environment for R. Boston, MA: RStudio, Inc. Available at: http://www.rstudio.com

Sarrazin J, Cuvelier D, Peton L, Legendre P, Sarradin PM (2014) High-resolution dynamics of a deep-sea hydrothermal mussel assemblage monitored by the EMSO-Açores MoMAR observatory. Deep-Sea Res Pt I 90:62-75. doi: 10.1016/i.dsr.2014.04.004

Sarrazin J, Legendre P, de Busserolles F, Fabri M-C, Guilini K, Ivanenko VN, Morineaux M, Vanreusel A, Sarradin P-M (2015) Biodiversity patterns, environmental drivers and indicator species on a high-temperature hydrothermal edifice, Mid-Atlantic Ridge. DeepSea Res Pt II 121:177-192. doi: 10.1016/i.dsr2.2015.04.013

Sasaki T, Warén A, Kano Y, Okutani T, Fujikura K (2010) Gastropods from Recent Hot Vents and Cold Seeps: Systematics, Diversity and Life Strategies. In: Kiel S (ed) The Vent and Seep Biota: Aspects from Microbes to Ecosystems. Springer Netherlands, Dordrecht, pp 169-254

Schneider CA, Rasband WS, Eliceiri KW (2012) NIH Image to ImageJ: 25 years of image analysis. Nat Methods 9:671-675. doi: 10.1038/nmeth.2089

Shank TM, Fornari DJ, Von Damm KL, Lilley MD, Haymon RM, Lutz RA (1998) Temporal and spatial patterns of biological community development at nascent deep-sea hydrothermal vents $\left(9^{\circ} 50^{\prime} \mathrm{N}\right.$, East Pacific Rise). Deep-Sea Res Pt II 45:465-515. doi: 10.1016/S0967-0645(97)00089-1

Sheader M, Van Dover CL, Shank TM (2000) Structure and function of Halice hesmonectes (Amphipoda: Pardaliscidae) swarms from hydrothermal vents in the eastern Pacific. Mar Biol 136:901-911. doi: 10.1007/s002270000300

Sheader M, Van Dover CL, Thurston MH (2004) Reproductive ecology of Bouvierella curtirama (Amphipoda: Eusiridae) from chemically distinct vents in the Lucky Strike vent field, Mid-Atlantic Ridge. Mar Biol 144:503-514. doi: 10.1007/s00227-003-1211-8

Sievert SM, Ziebis W, Kuever J, Sahm K (2000) Relative abundance of Archaea and Bacteria along a thermal gradient of a shallow-water hydrothermal vent quantified by rRNA slotblot hybridization. Microbiol 146 (Pt 6):1287-1293. doi: 10.1099/00221287-146-6-1287

Smith CR, Kukert H, Wheatcroft RA, Jumars PA, Deming JW (1989) Vent fauna on whale remains. Nature 341:27-28. doi: 10.1038/341027a0

Suzuki K, Yoshida K, Watanabe H, Yamamoto H (2018) Mapping the resilience of chemosynthetic communities in hydrothermal vent fields. Sci Rep 8:9364. doi: 10.1038/s41598-018-27596-7

Turnipseed M, Jenkins CD, Van Dover CL (2004) Community structure in Florida Escarpment seep and Snake Pit (Mid-Atlantic Ridge) vent mussel beds. Mar Biol 145:121-132. doi: 10.1007/s00227-004-1304-z

Tyler PA, Billett DSM (1988) The Reproductive Ecology of Elasipodid Holothurians from the N. E. Atlantic. Biological Oceanography 5:273-296. doi: 10.1080/01965581.1987.10749518 Tyler PA, 1988. Seasonality in the deep-sea. Oceanogr Mar Biol. Annual Review 26: 227-258.

Tyler PA, Campos-Creasey, L.S. and Giles, L.A., 1994. Environmental control of quasicontinuous and seasonal reproduction in deep-sea benthic invertebrates. In Reproduction, Larval Biology and Recruitment of the Deep-Sea Benthos, edited by C. M. Young and K. J. Eckelbarger. New York: Columb U Pr, pp. 158-178.

Tyler PA, Young CM (1999) Reproduction and dispersal at vents and cold seeps. J Mar Biol Assoc UK 79:193-208. doi: 10.1017/S0025315499000235

Tyler PA, Pendlebury S, Mills SW, Mullineaux L, Eckelbarger KJ, Baker M, Young CM (2008) Reproduction of Gastropods from Vents on the East Pacific Rise and the Mid-Atlantic 
Ridge. J Shellfish Res. 27:107-118. doi: 10.2983/07308000(2008)27[107:ROGFVO]2.0.CO;2

Van Dover CL (2014) Impacts of anthropogenic disturbances at deep-sea hydrothermal vent ecosystems: A review. Mar Environ Res 102:59-72. doi: 10.1016/j.marenvres.2014.03.008

Van Dover CL, Trask J, Gross J, Knowlton A (1999) Reproductive biology of free-living and commensal polynoid polychaetes at the Lucky Strike hydrothermal vent field (MidAtlantic Ridge). Mar Ecol Progr Ser 181:201-214. doi: 10.3354/meps181201

Vic C, Gula J, Roullet G, Pradillon F (2018) Dispersion of deep-sea hydrothermal vent effluents and larvae by submesoscale and tidal currents. Deep-Sea Res Pt I 133:1-18. doi: 10.1016/i.dsr.2018.01.001

Vrijenhoek RC (2010) Genetic diversity and connectivity of deep-sea hydrothermal vent metapopulations. Mol Ecol 19:4391-4411. doi: 10.1111/j.1365-294X.2010.04789.x

Warèn A, Bouchet $P$ (2001) Gastropoda and Monoplacophora from hydrothermal vents and seeps ; new taxa and records. The Veliger 44:116-231.

Warèn A, Bouchet $P$ (1993) New records, species, genera, and a new family of gastropods from hydrothermal vents and hydrocarbon seeps. Zool Scr 22:1-90. doi: 10.1111/j.14636409.1993.tb00342.x

Warén A (1996) New and little known mollusca from Iceland and Scandinavia. Part 3. Sarsia 81:197-245. doi: 10.1080/00364827.1996.10413622

Watanabe H, Kado R, Kaida M, Tsuchida S, Kojima S (2006) Dispersal of vent-barnacle (genus Neoverruca) in the Western Pacific. Cah Biol Mar 47: 353-357

Watanabe H, Fujikura K, Kinoshita G et al (2009) Egg capsule of Phymorhynchus buccinoides (Gastropoda: Turridae) in a deep-sea methane seep site in Sagami Bay, Japan. Venus 67:181-188

Yahagi T, Watanabe HK, Kojima S, Kano Y (2017) Do larvae from deep-sea hydrothermal vents disperse in surface waters? Ecology 98:1524-1534. doi: 10.1002/ecy.1800

Young CM, Eckelbarger KJ, Eckelbarger K (1994) Reproduction, Larval Biology, and Recruitment of the Deep-sea Benthos. Columb U Pr

Young CM. (2003) Reproduction, Development and Life History Traits, in: Ecosystems of the World, Vol. 28, Ecosystems of the Deep Oceans, edited by: Tyler, P. A., Elsevier, London, 381-426

Zal $F$, Jollivet $D$, Chevaldonné $P$, Desbruyères $D(1995)$ Reproductive biology and population structure of the deep-sea hydrothermal vent worm Paralvinella grasslei (Polychaeta: Alvinellidae) at $13^{\circ} \mathrm{N}$ on the East Pacific Rise. Mar Biol122:637-648. doi: 10.1007/BF00350685

Zar JH (2007) Biostatistical Analysis (5th Edition). Prentice-Hall, Inc., Upper Saddle River, NJ, USA 

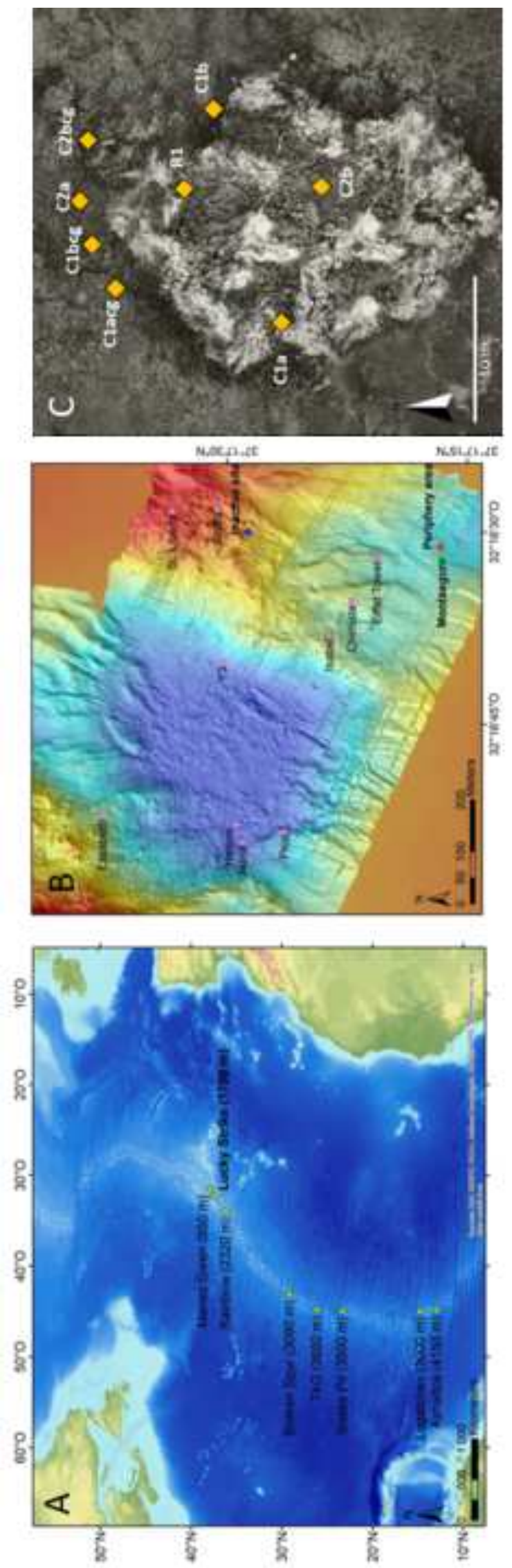

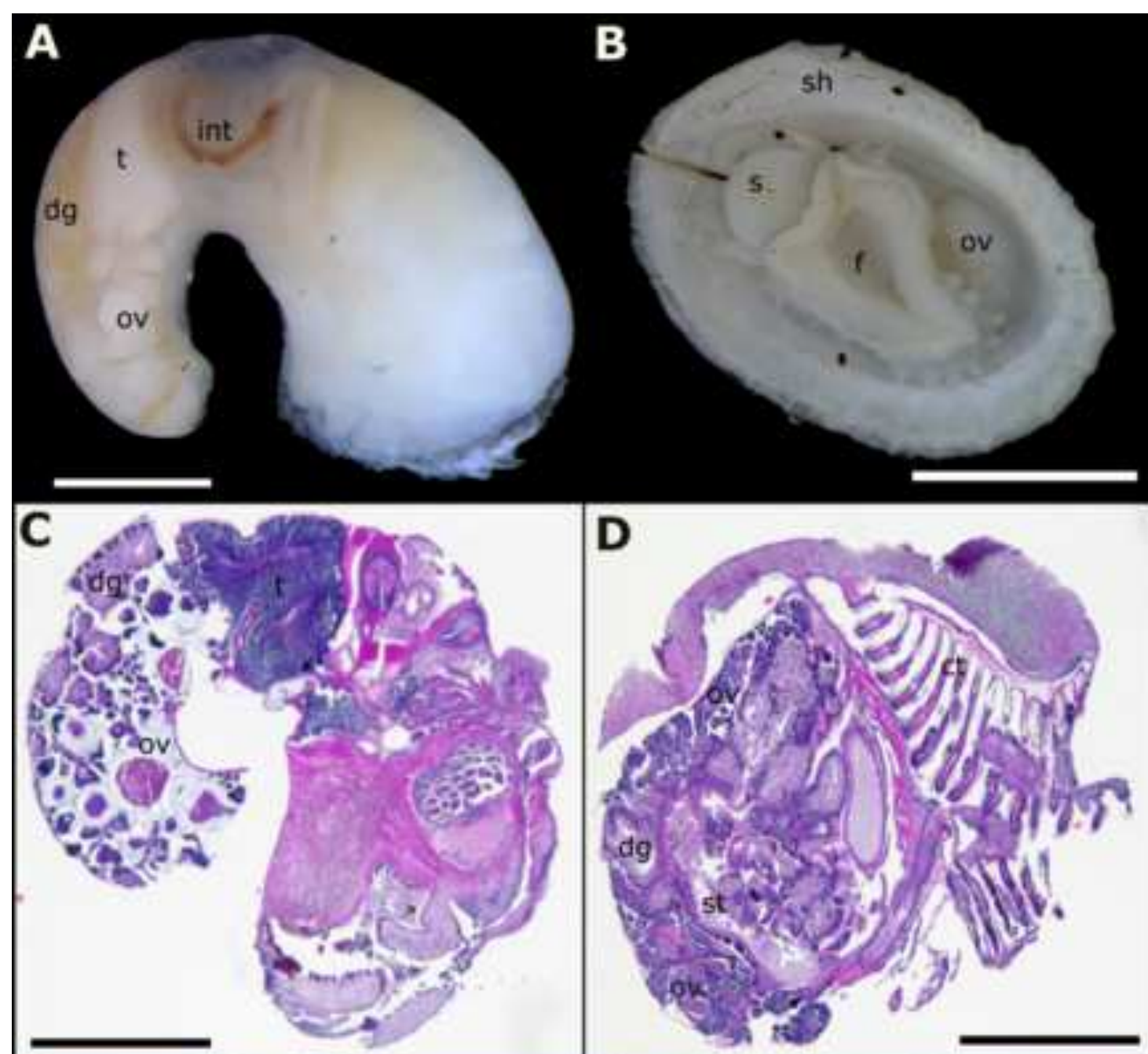

D
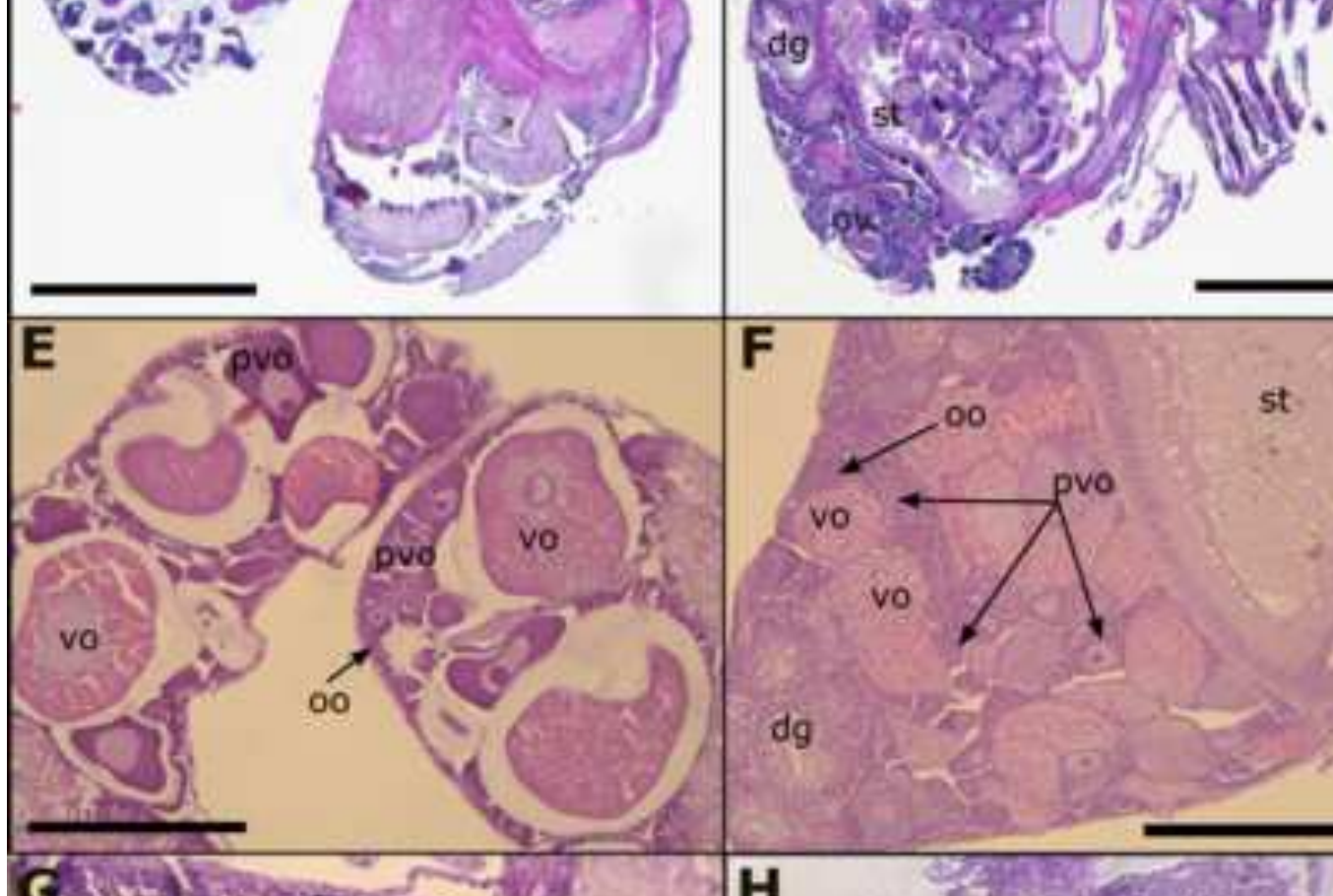

$\mathrm{dg}$

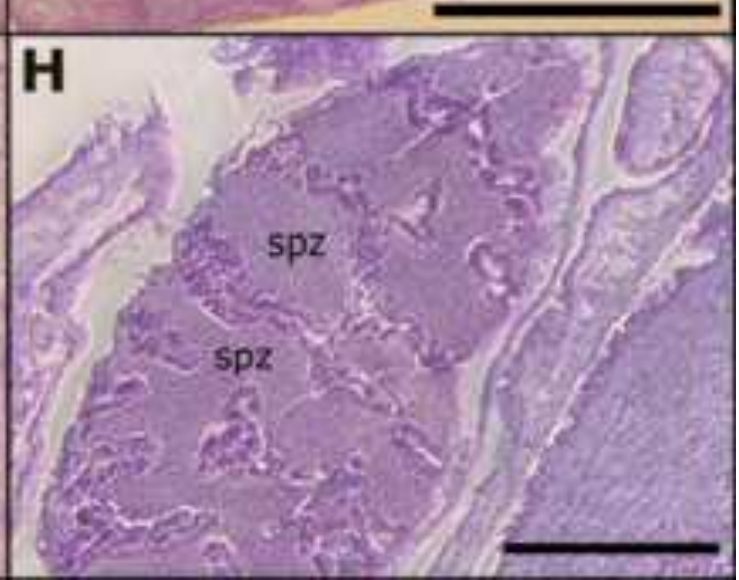




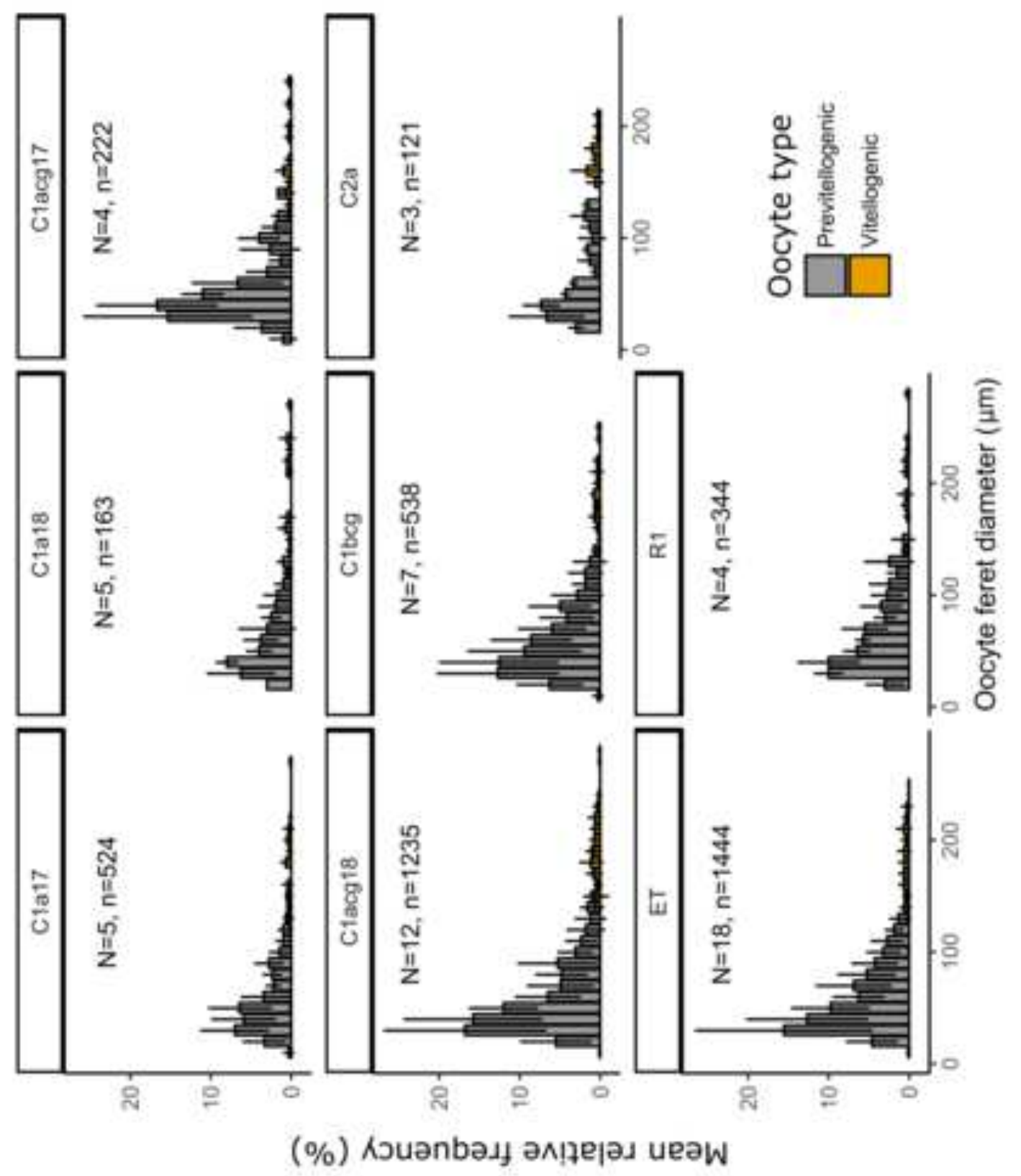




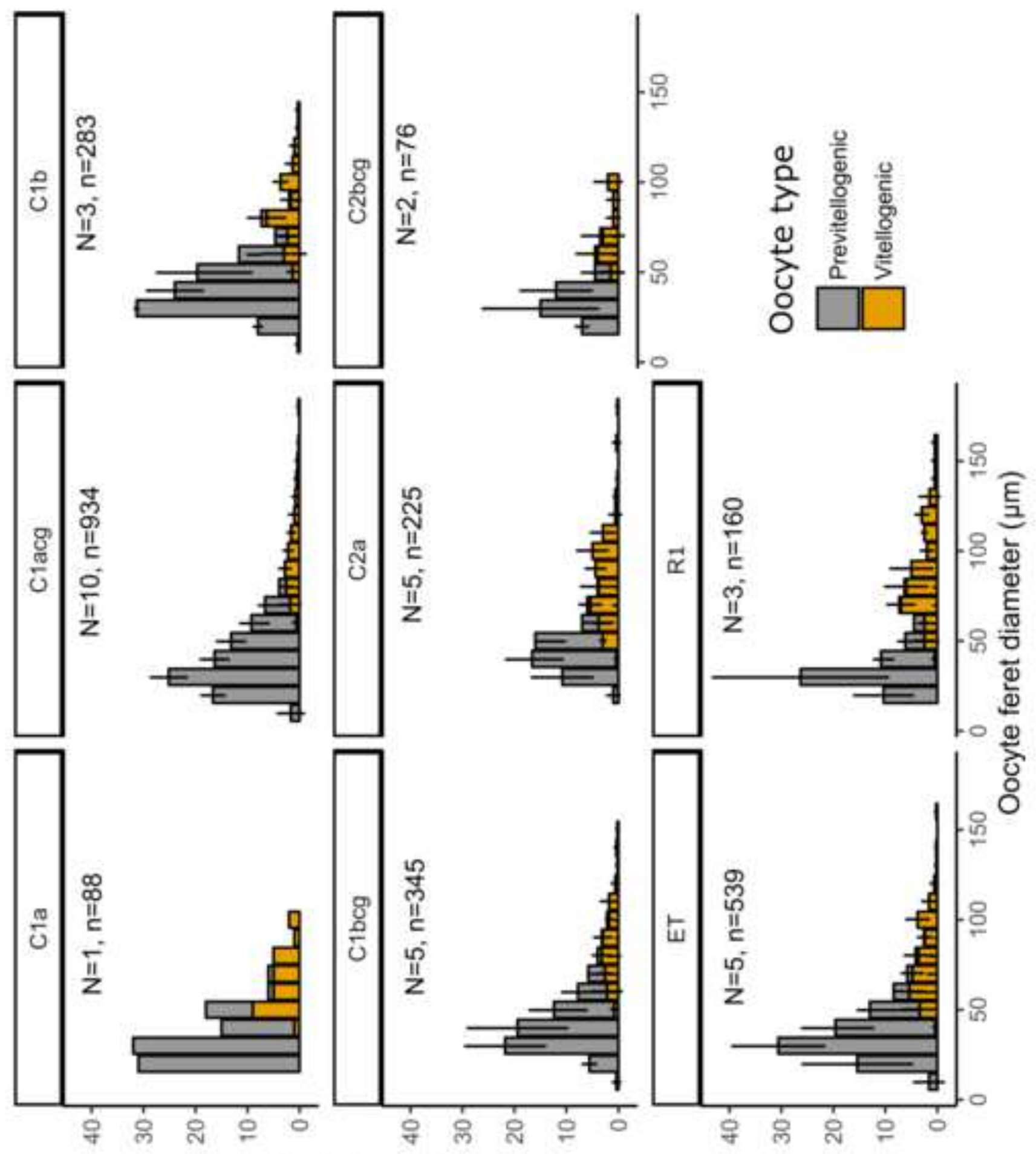

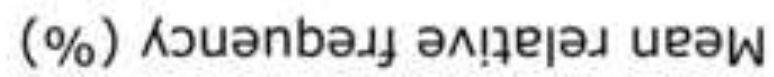




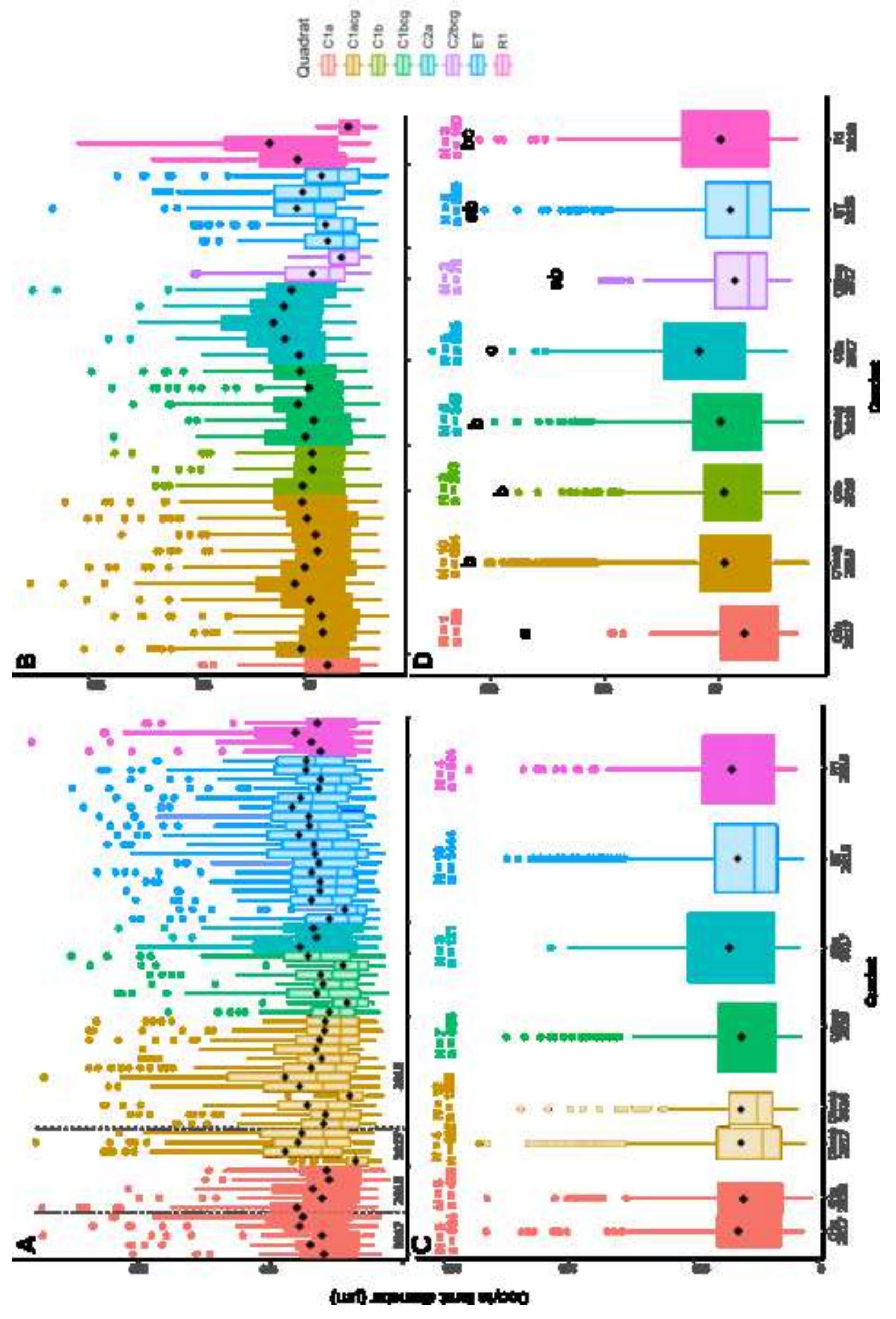

욤 


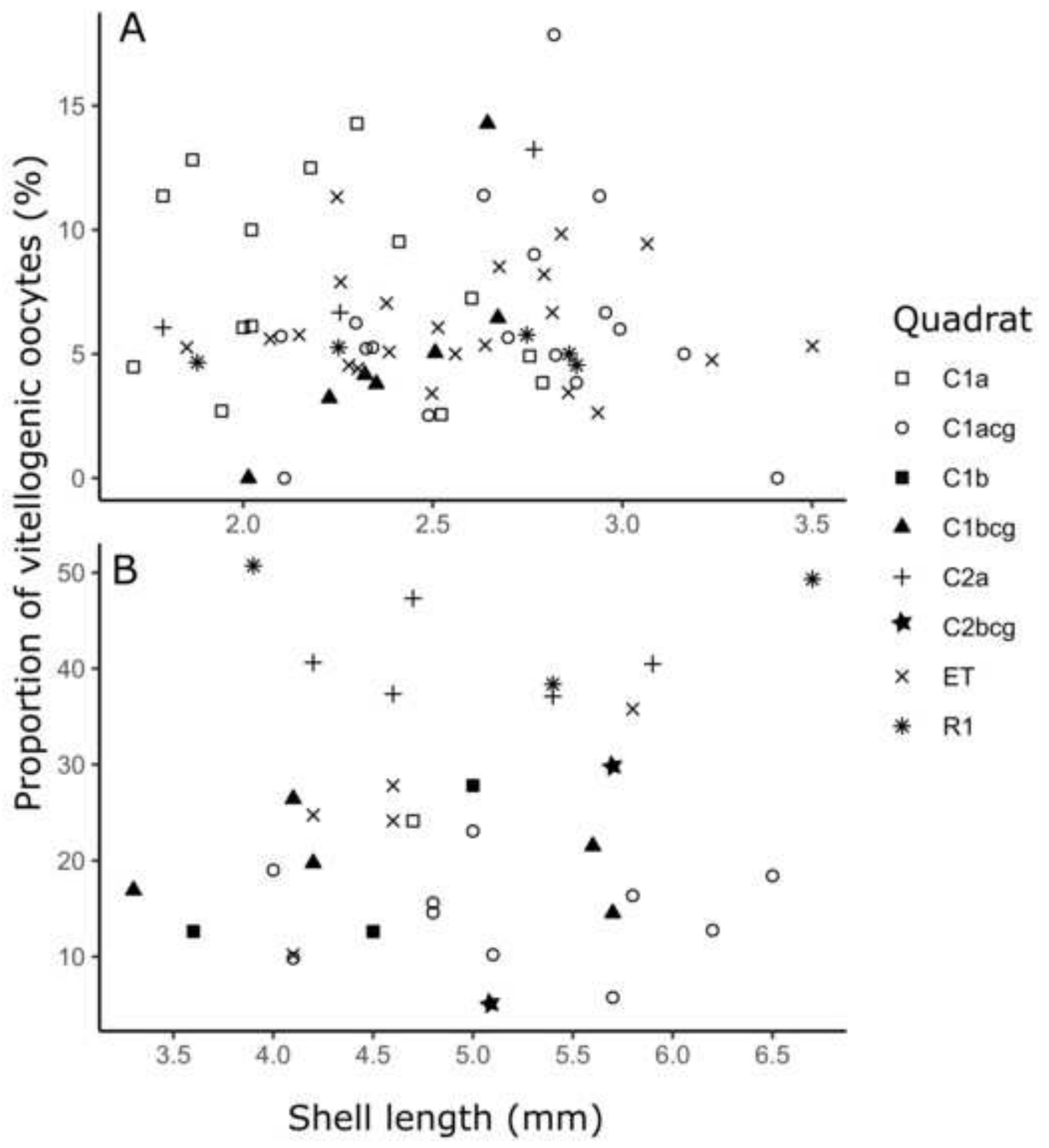



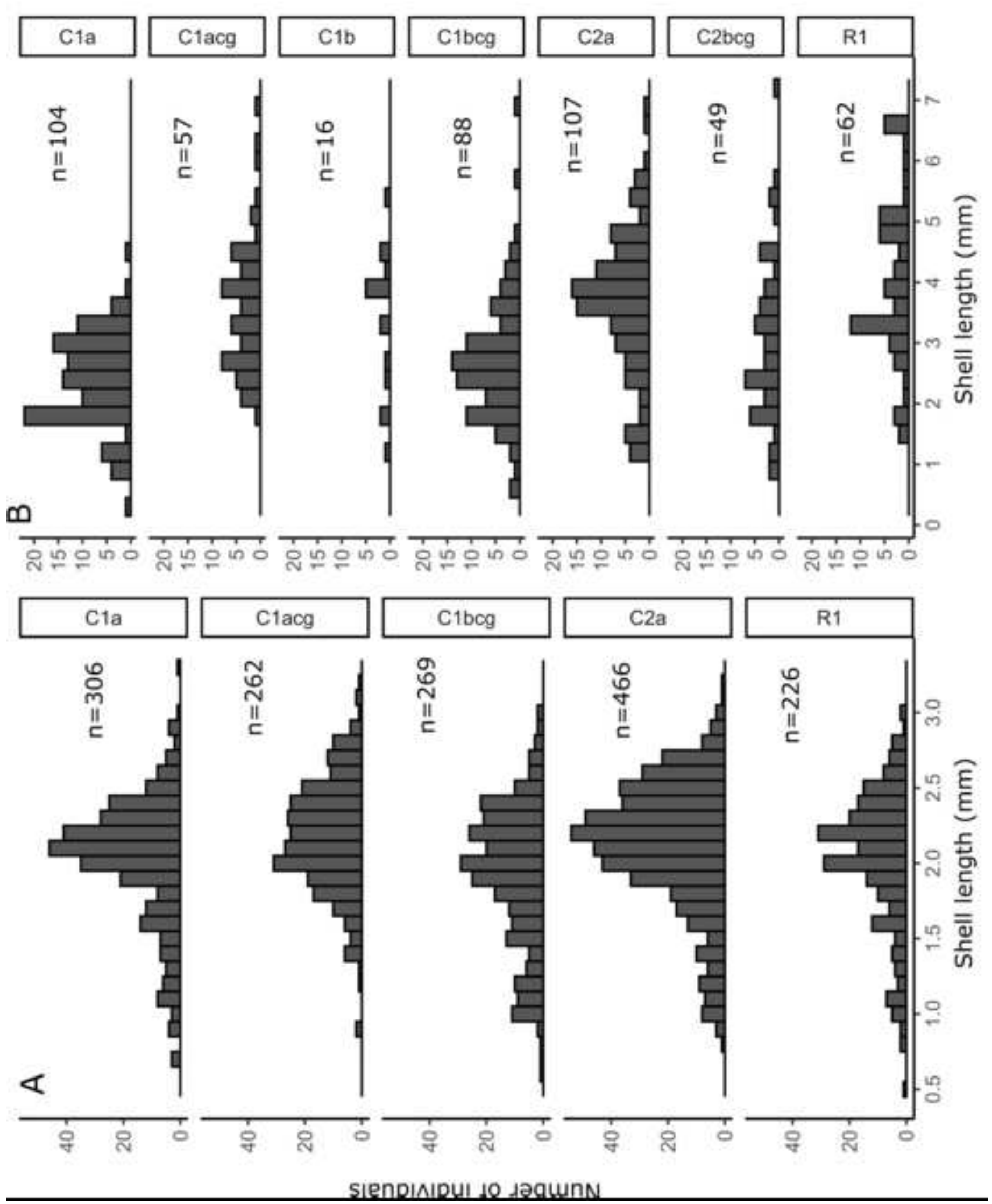
Click here to access/download Supplementary Material FigS1.png 
Click here to access/download Supplementary Material FigS2.png 